\title{
Precise Determination of the Ascendant in the Lagnaprakarana - II
}

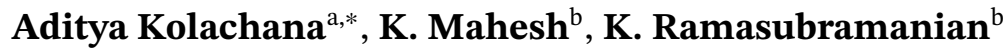 \\ a Indian Institute of Technology Madras. \\ ${ }^{\mathrm{b}}$ Indian Institute of Technology Bombay.
}

(Received 04 February 2020)

\begin{abstract}
Authored by the celebrated mathematician-astronomer Mādhava, the Lagnaprakarana is an important astronomical text dedicated to the determination of the udayalagna or the ascendant, and is notable for its technical brilliancy and multiple approaches to a given problem. In continuation of our previous papers on this text, here we discuss some more methods for precisely determining the udayalagna as described in the second chapter of the Lagnaprakarana.
\end{abstract}

Key words: Ascendant, Dṛkkṣepajyā, Dṛkkṣepakoțikā, Kālalagna, Lagna, Lagnaprakaraṇa, Mādhava, Rāśikūtalagna, Rāśikūṭaprabhā, Udayalagna.

\section{Introduction}

In our previous paper ${ }^{1}$ we discussed the first method described by Mādhava for precisely determining the ascendant in the Lagnaprakarana. There, the procedure involved first determining the drkkșepalagna or the nonagesimal, and then determining the udayalagna therefrom. In this paper, we discuss three other methods described by Mādhava for precisely determining this quantity. These methods, described in the second chapter of the Lagnaprakarana, involve determining the ascendant from (i) the rāśsikūtalagna, (ii) the unmandalalagna, and (iii) the kālalagna. It may be noted that this paper is to be read in conjunction with our earlier paper as various physical and mathematical quantities described therein are employed here as well. Thus, readers are directed to our previous paper for all references to verses $31-38$ in the current paper.

\section{DOI: $10.16943 / \mathrm{ijhs} / 2020 / v 55 i 1 / 152339$}

${ }^{*}$ Corresponding author: aditya.kolachana@gmail.com

${ }^{1}$ See [9]. Also see [8], [10], and [7] for our discussion on some of the foundational astronomical parameters described by Mādhava in the first chapter of the Lagnaprakarana.
In the following discussion, it may be reiterated that we employ the symbols $\lambda, \alpha, \delta$, and $z$ to respectively refer to the longitude, right ascension, declination, and zenith distance of a celestial body. The kâlalagna, the latitude of the observer, and the obliquity of the ecliptic are denoted by the symbols $\alpha_{e}, \phi$, and $\epsilon$ respectively. It may also be mentioned that all the figures in this paper depict the celestial sphere for an observer having a northerly latitude $\phi$. In these figures, $N, S, E$, and $W$ denote the cardinal directions north, south, east, and west, while $P$ and $K$ denote the poles of the celestial equator and the ecliptic respectively.

\section{Determining the ascendant from the rāśikūțalagna}

In this section, we discuss the first of the three methods to be discussed in this paper for determining the udayalagna, as outlined in five verses (39-43) of the second chapter of the Lagnaprakarana. The procedure involves determining the udayalagna from the rāśikuttalagna, the drkkșepajya and other quantities. To this end, verses 
39-41 describe an alternate ${ }^{2}$ method of determining the drkkșepajya , while verses 42 and 43 prescribe two relations for calculating the udayalagna from the rāśikuttalagna, using the dṛkșepajyā and other quantities. Readers may refer to our previous paper for further details on the rāśikūtalagna.

\subsection{Alternate expression for the dṛksșepajyā}

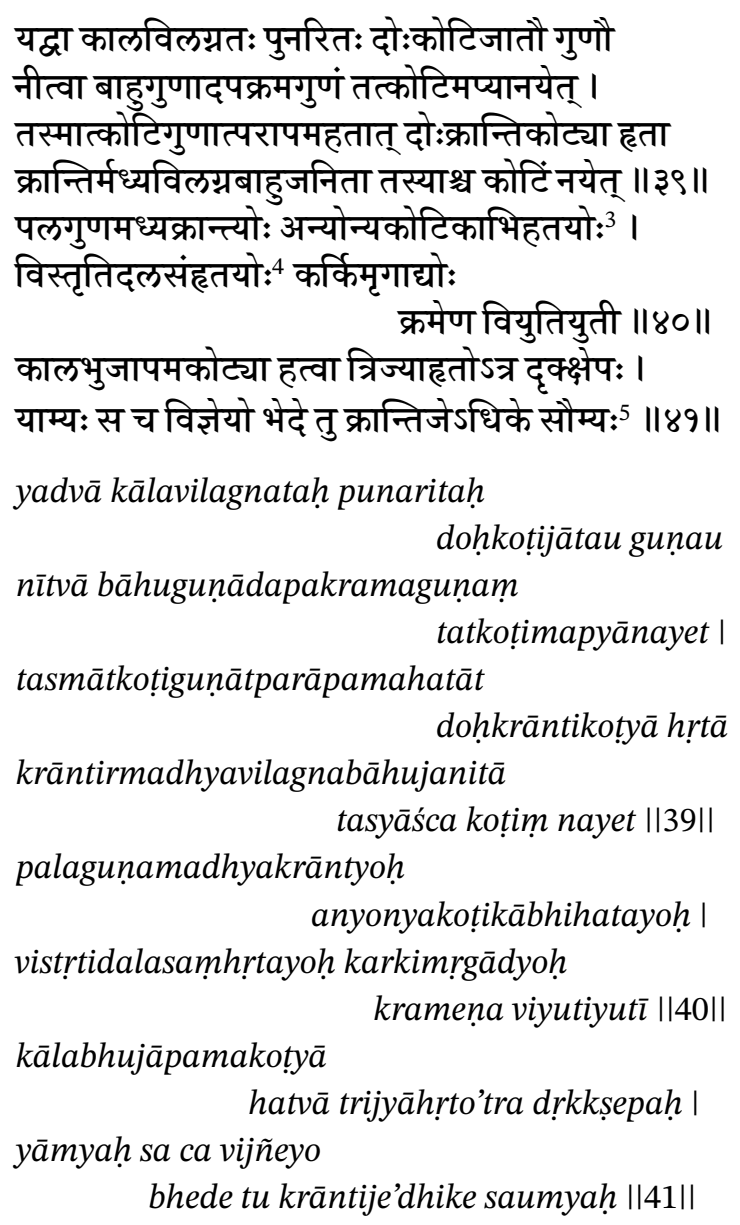

Or, again having computed the Rsine and Rcosine from this kālalagna, one should compute the Rsine of the declination from the Rsine of the

\footnotetext{
${ }^{2}$ See our previous paper for the first relation given in the Lagnaprakarana for this quantity.

${ }^{3}$ Manuscripts read कोटिकाहतयो:. However, this does not fit any known metre. We have emended the text to satisfy the metrical constraints of the udgiti metre, without any change in meaning.

${ }^{4}$ Manuscripts read विस्तृतिदलसंहतयो:. We have emended this likely scribal error as the mathematical procedure requires division by $R$ and not multiplication.

${ }^{5}$ Manuscripts read सौम्यम्. The scribal error is evident as saumya is used as an adjective to the masculine noun drkkșepa in the verse.
}

$b \bar{a} h u$ [of the kālalagna] and also the Rcosine of that [declination] (i.e. dohkrāntikoți or kālabhujāpamakotil). That [former] Rcosine multiplied by [the Rsine of] the maximum declination (parāpama) is divided by the dohkrāntikoți. That [resulting quantity] is [the Rsine of] the declination (krānti) obtained from the longitude of the meridian ecliptic point (madhyavilagna). One should also compute the Rcosine of that [declination].

The [Rsine of this] declination and the Rsine of the latitude multiplied by the Rcosines of each other and divided by the semi-diameter (vistrtidala) would be subtracted or added [depending on $k \bar{a}$ lalagna's position] in the six signs from Cancer (karki) or Capricorn ( $m r g a)$ respectively.

Having multiplied [that sum or difference] by the $k \bar{a} l a b h u j a \overline{a p a m a k o t i t}$, and divided by the radius (tri$j y \bar{a}$ ), [one obtains the] drkkksepa[jyā] here. That is to be known to be southern [generally]. It is northern if the Rsine of the declination [of the meridian ecliptic point] is greater [than the Rsine of the latitude] when they differ [in their directions].

The verses above give another relation to determine the

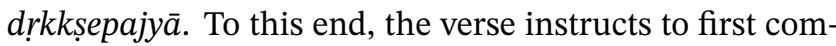
pute the Rsine and Rcosine of the kālalagna, and then to also compute the Rsine and Rcosine of the so called declination from the kālalagna, which corresponds to the arc $E R=\mu$ in Figure $1 .{ }^{6}$

Having computed these quantities, as a precursor to determining the drkksepajyā, the verse gives the following relation to obtain the Rsine of the declination of the meridian ecliptic point, known as the madhyakrāntijyā:

madhyakrāntijyā $=\frac{k \bar{a} l a l a g n a-k o t ̦ i g u n ̣ a \times \text { parāpamajyā }}{\text { doḥkrāntikoṭi }}$ or,

$$
R \sin \delta_{m}=\frac{R \cos \alpha_{e} \times R \sin \epsilon}{R \cos \mu} .
$$

From this we are asked to determine $R \cos \delta_{m}$, and to use these quantities to determine the $d r k k s e p a j y \bar{a}$ as follows:

$$
\begin{aligned}
& \text { dṛkkṣepa }= \\
& (\text { kālabhujāpamakoți } \times[\text { palaguṇa } \times \text { madhyakrāntikoṭi } \\
& \pm \text { palakoṭi } \times \text { madhyakrāntiguṇa }] \div \text { vistṛtidala }) \div \text { trijya }
\end{aligned}
$$

${ }^{6}$ We have shown one method of determining $\sin \mu$ in our discussion of verse 36 . Another method is shown below. 


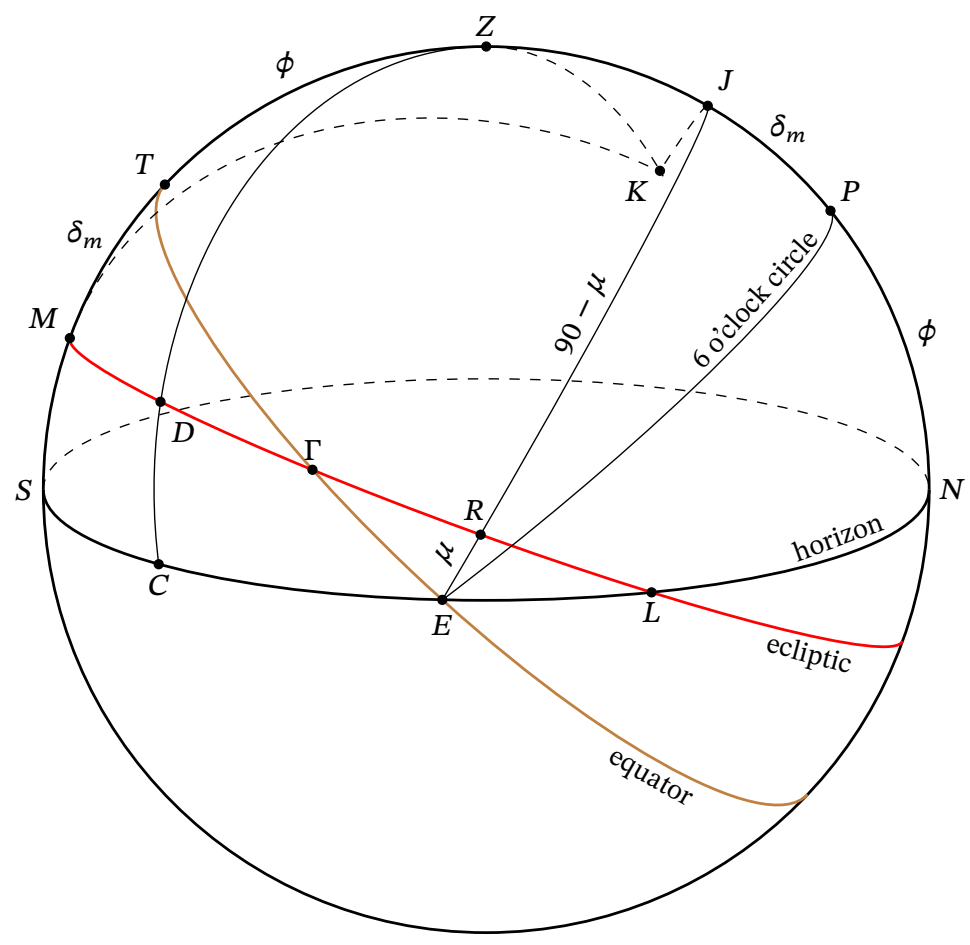

Figure 1 Visualising the drikksepa.

or,

$$
\begin{aligned}
R \sin z_{d} & =\frac{R \cos \mu \times \frac{R \sin \phi \times R \cos \delta_{m} \pm R \cos \phi \times R \sin \delta_{m}}{R}}{R} \\
& =\frac{R \cos \mu \times R \sin z_{m}}{R},
\end{aligned}
$$

where $z_{m}$ is the zenith distance of the madhyalagna, discussed in our previous paper.

\section{Obtaining the madhyakrāntijyā}

The expression for the madhyakrāntijyā given in (1) can be easily verified from the spherical triangle $\Gamma E R$ in Figure 1. Noting that the point $R$ in this triangle is the rāśi$k u$ țalagna, we have

$$
\Gamma \hat{R} E=90, \quad \text { and } \quad \Gamma R=\lambda_{m}+90 .
$$

Also, by definition

$$
\Gamma E=\alpha_{e}, \quad E \hat{\Gamma} R=\epsilon, \quad \text { and } \quad E R=\mu .
$$

Applying the sine rule in this triangle, we obtain

$$
\begin{aligned}
\sin \mu & =\sin \alpha_{e} \sin \epsilon, \\
\text { or, } \quad R \sin \mu & =\frac{R \sin \alpha_{e} \times R \sin \epsilon}{R},
\end{aligned}
$$

(4) It may be noted that a similar usage has been encountered in verse 36 (see our previous paper), where the term kotikrānti refers to the (5) 'declination' derived from the cosine of the longitude of the madhyalagna. where $\alpha_{e}$ and $\epsilon$ are both known. Comparing (4) with the expression for the sine of the declination of the Sun given by $\sin \delta=\sin \lambda \sin \epsilon$, one can view the above result as the sine of the 'declination' derived from the sine of the kâlalagna instead of the sine of the longitude of the Sun. Therefore, the expression $\sin \alpha_{e} \sin \epsilon$ is referred to as the 'sine of the declination derived from the $b \bar{a} h u$ (of the kālalagna)' ${ }^{7}$ in verse 39. Having determined $R \sin \mu$, the verse prescribes to also determine the $\operatorname{cosine} R \cos \mu$, which is easily done using basic trigonometry. This cosine is referred to as the dohkrāntikoți in verse 40 and as the $k \bar{a}$ labhujāpamakoți in verse 41 , which can be translated as 'the cosine of the declination derived from the doh or bhujā of the kālalagna'.

Now, applying the cosine rule in the spherical triangle $\Gamma E R$, we have

$$
\cos \alpha_{e}=\cos \left(\lambda_{m}+90\right) \cos \mu,
$$




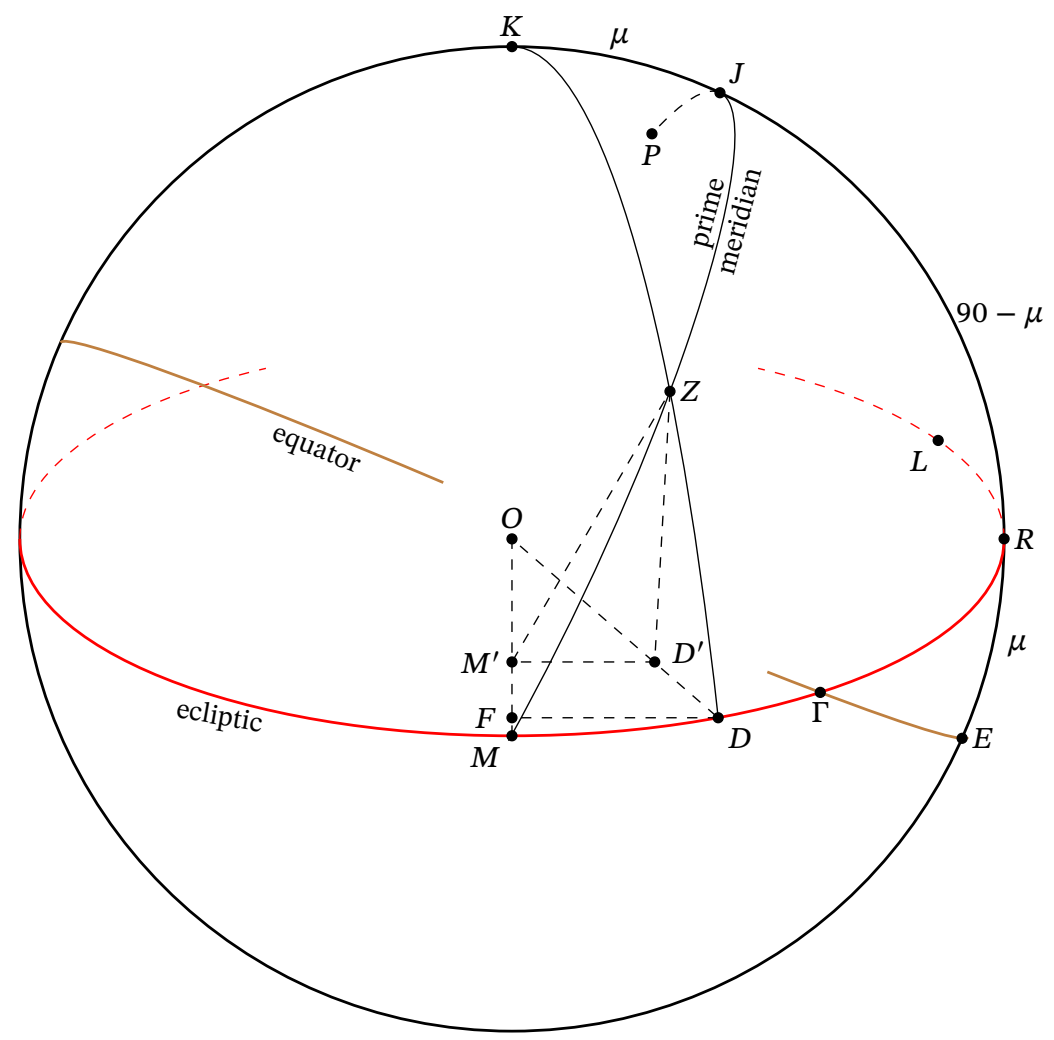

(a) Visualising the drkkșepa from the point of view of the ecliptic plane.
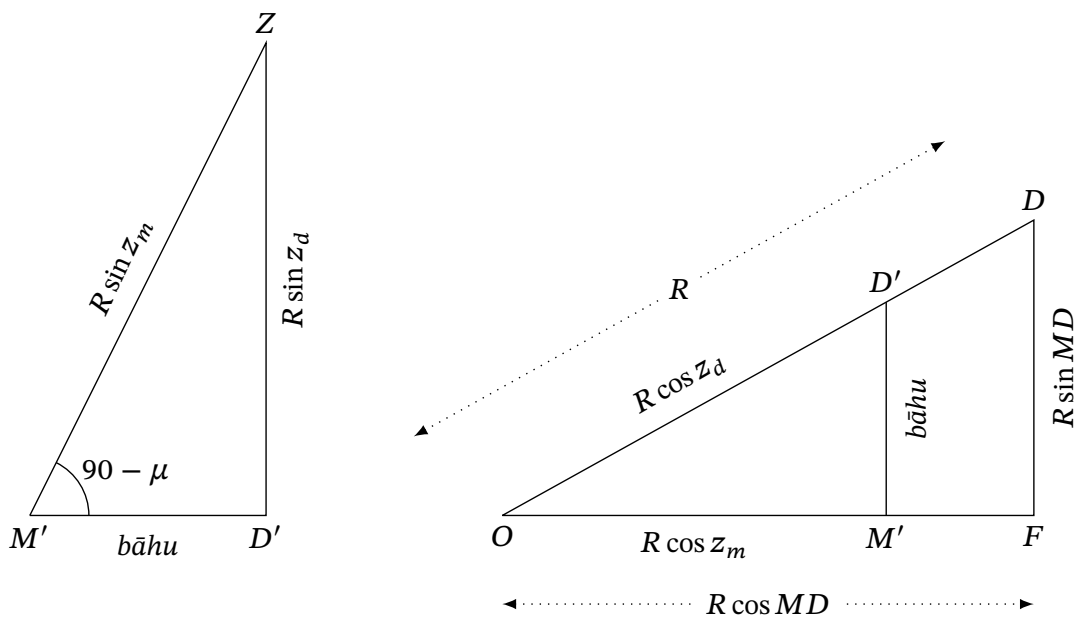

(b) Planar triangles used to determine the dṛkkșepajya and the dṛksṣepalagna.

Figure 2 Determining the dṛkṣepajya and the drkkșepalagna. 
or,

$$
\sin \lambda_{m}=\frac{-\cos \alpha_{e}}{\cos \mu} .
$$

Now, since $\sin \delta_{m}=\sin \lambda_{m} \sin \epsilon$, we have

$$
\sin \delta_{m}=\frac{-\cos \alpha_{e} \times \sin \epsilon}{\cos \mu}
$$

which differs from (1) only with regards to the sign. As the author discusses the application of the sign later in the second half of verse 40 , while giving the relation for the drkksepajya $\bar{a}$, we too discuss this towards the end of the next section.

\section{Determining the dṛkkșepajyā}

The given relation for the dṛkssepajya can be readily understood from the right-angled triangle $Z M^{\prime} D^{\prime}$ in Figure $2 b,{ }^{8}$ where it can be seen that

$$
R \sin z_{d}=R \sin z_{m} \times \cos \mu,
$$

which is the same as (3). The expression for $R \sin z_{m}$ given in the verse as

$$
R \sin z_{m}=\frac{R \sin \phi \times R \cos \delta_{m} \pm R \cos \phi \times R \sin \delta_{m}}{R},
$$

is the same as the one given in verse 35 , discussed in our earlier paper. As explained in our discussion of the madhyajy $\bar{a}$ there, the terms in the above expression are added or subtracted depending upon whether the equator and the zenith are on the same or opposite sides of the ecliptic. Here, an equivalent rule is given, which states that the terms of the above expression have to be subtracted or added depending upon whether the kālalagna is in the six signs starting from Cancer or Capricorn respectively. That is, the second term is to be subtracted from the first when the kālalagna is in the range of $90 \mathrm{de}-$ grees to 270 degrees, and added when it is in the range of 270 degrees to 90 degrees. This rule can be understood purely from physical considerations, or through mathematical analysis.

Physically, the madhyalagna has southern declination when the kālalagna is in the range of 270 degrees to 90 degrees, and northern declination otherwise. An instance of

\footnotetext{
${ }^{8}$ The planar triangles in this figure are the same as those shown in Figure 2a, which depicts the celestial sphere from the point of view of the ecliptic plane. For further details on this figure, see our discussion on verse 36 in our previous paper.
}

the former case is depicted in Figure 3a, where the kālalagna $(\Gamma E)$ is in the first quadrant, and the madhyalagna $(M)$ has southern declination. An instance of the latter case is depicted in Figure 3b, where the kālalagna is in the third quadrant, and the madhyalagna has northern declination. In the former case, it is clearly evident that

$$
\sin z_{m}=\sin \left(\phi+\delta_{m}\right)=\sin \phi \cos \delta_{m}+\cos \phi \sin \delta_{m},
$$

while in the latter case, clearly

$$
\sin z_{m}=\sin \left(\phi-\delta_{m}\right)=\sin \phi \cos \delta_{m}-\cos \phi \sin \delta_{m} .
$$

Approaching the problem purely from a mathematical viewpoint, we observe that the first term $\left(\sin \phi \cos \delta_{m}\right)$ in the above expressions is always positive, ${ }^{9}$ while the second term $\left(\cos \phi \sin \delta_{m}\right)$ can be positive or negative depending upon the sign of the declination..$^{10}$ From (1), we see that $\sin \delta_{m}$ takes the sign of the term $\cos \alpha_{e},{ }^{11}$ which being a cosine function is negative in the range $90 \mathrm{de}$ grees to 270 degrees (Cancer etc.), and positive otherwise (Capricorn etc.). Therefore, the absolute magnitude of the term $\cos \phi \sin \delta_{m}$ is to be subtracted from or added to the term $\sin \phi \cos \delta_{m}$ depending upon whether the kālalagna lies in those quadrants where the cosine function is negative or positive. This is exactly the rule stated in the verse.

For an observer in the northern hemisphere, the drkkșepajya will generally be seen in the southern hemisphere as shown in Figure 4a. However, for observers at lower latitudes $(\phi<\epsilon)$, occasionally the dṛkșepajyā may appear in the northern hemisphere when the declination of the madhyalagna is northwards, and also greater than the latitude of the observer, as shown in Figure $4 b$. These indeed are the observations that are made in the second half of verse 41 .

\subsection{Determining the udayalagna}

The following two verses give two relations for obtaining the udayalagna from the rāsikütalagna, employing the drkkșepajya and some other quantities derived earlier.

\footnotetext{
${ }^{9}$ As $0<\phi<90$, the term $\sin \phi$ is always positive. Also, as $-\epsilon<$ $\delta_{m}<\epsilon$, the term $\cos \delta_{m}$ is also always positive.

${ }^{10}$ Here again, since $0<\phi<90$, the term $\cos \phi$ is always positive.

${ }^{11}$ In (1), the term $\sin \epsilon$ is always positive. Also, from (4), we can deduce that $-\epsilon<\mu<\epsilon$. Therefore, the term $\cos \mu$ too is always positive.
} 


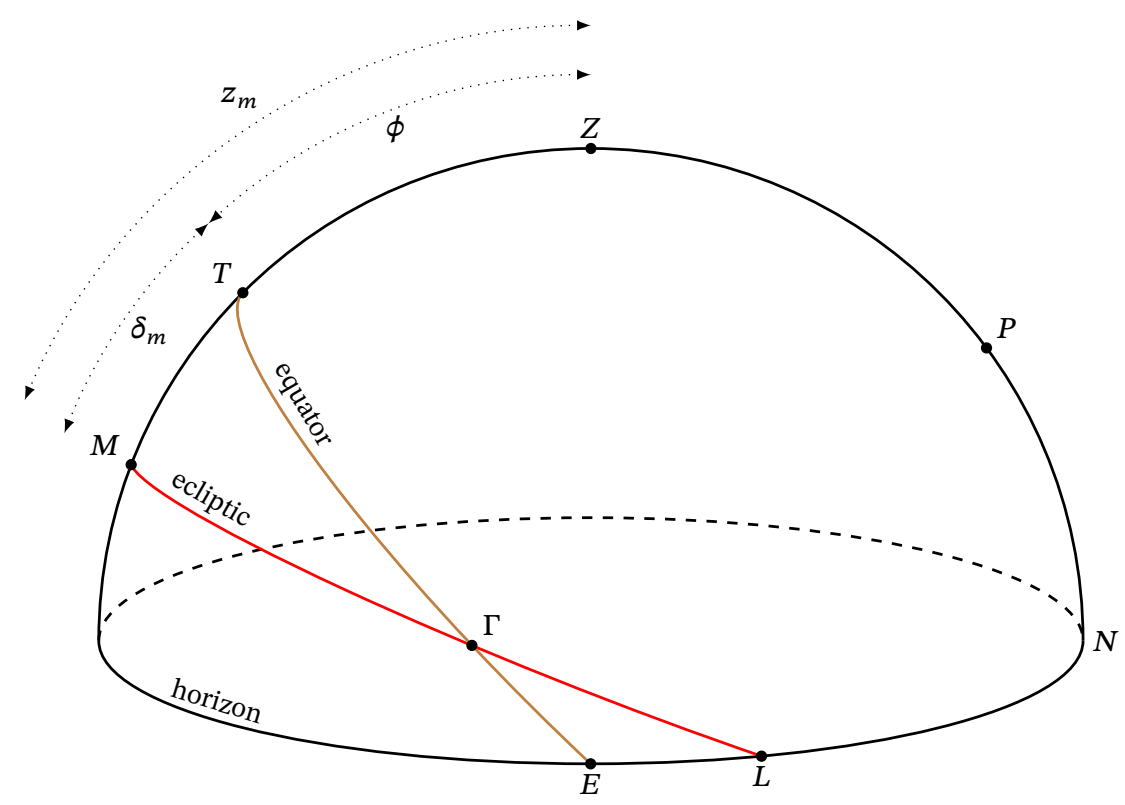

(a) Same direction.

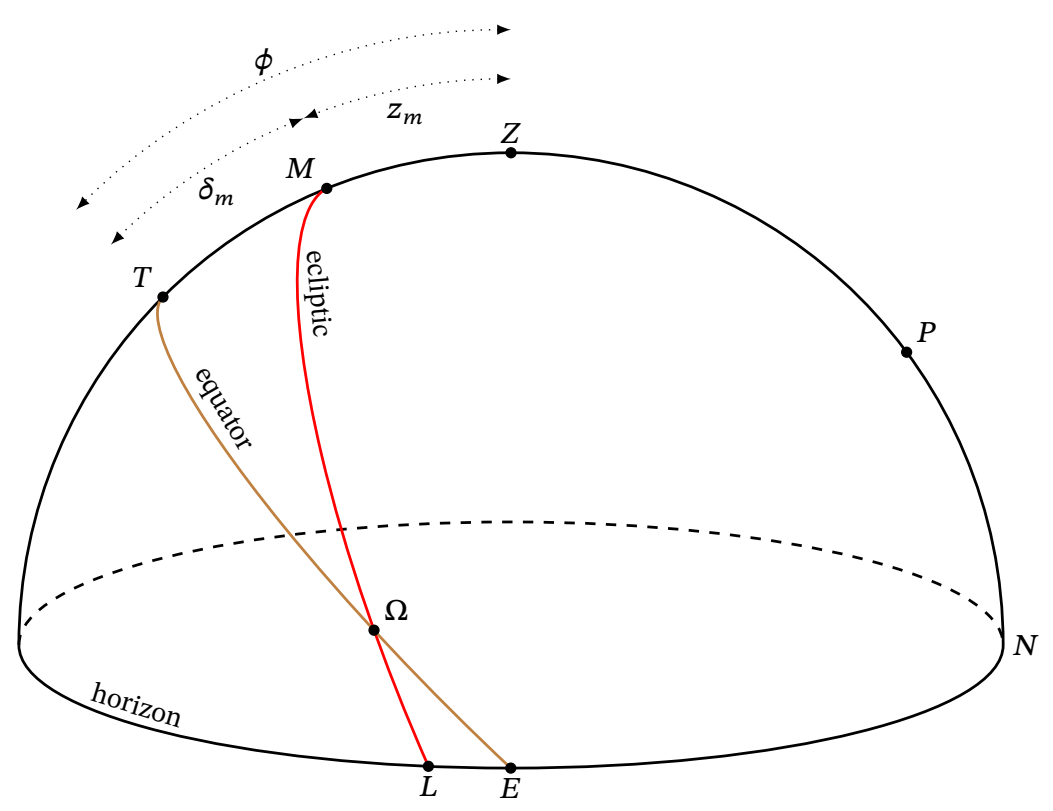

(b) Opposite directions.

Figure 3 The direction of the equator and the zenith with respect to the ecliptic for determining the madhyajya . 


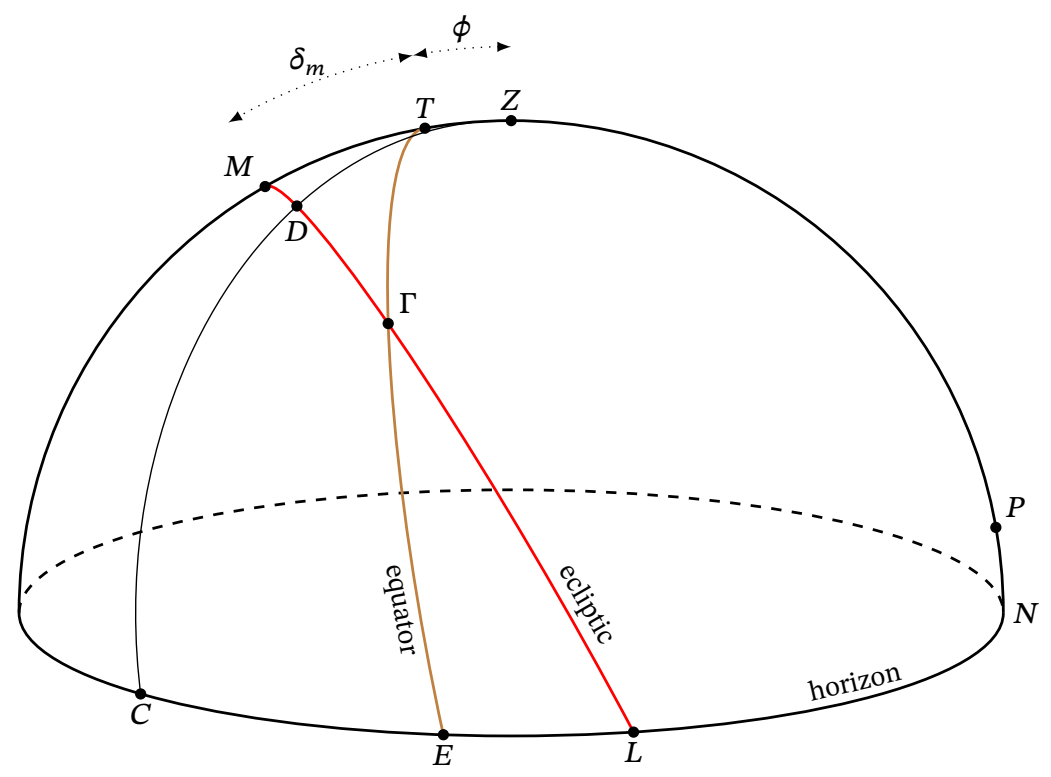

(a) Southern hemisphere.

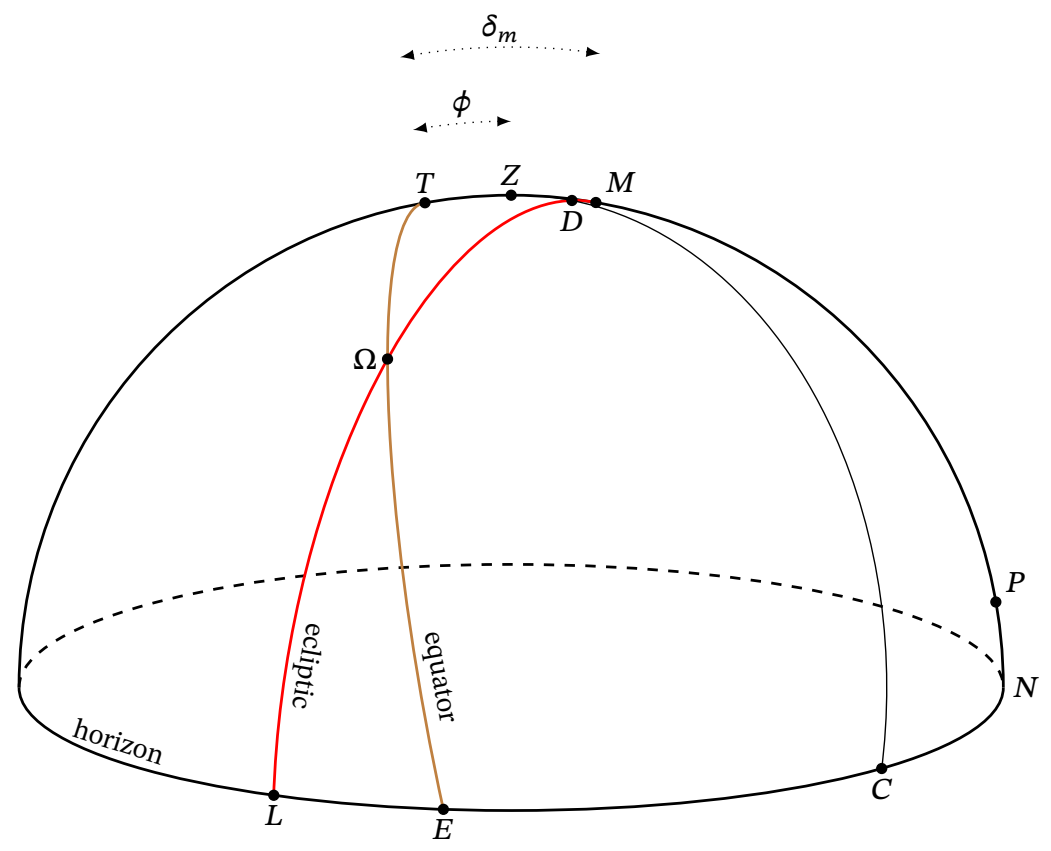

(b) Northern hemisphere.

Figure 4 Direction of the drkkșepa. 


\subsubsection{Method 1}

दृक्क्षेपाहतकालबाह्वपमतो दृक्क्षेपकोट्या हतं विष्कम्भार्धसमाहतं भुजभवद्युज्याहतं चापितम्। स्वर्णं कालविलग्रके कृतकलाप्राणान्तरे च क्रमात् दृक्क्षेपापमदिगिैदैक्यवरातः प्राग्लग्रसंसिद्धये ॥४र॥

drkkșepāhatakālabāhvapamato drkkșepakotyā hrtam

viṣkambhārdhasamāhatam bhujabhavasvarnạ̣ kālavilagnake krtakalādyujyāhṛtam cāpitam |

drkkṣepāpamadigbhidaikyavaśatah prāṇāntare ca kramāt prāglagnasaṃsiddhaye ||42||

[The result] from the division of [the Rsine of] the declination calculated from the kālalagna (kālabāhu-apama)-which is multiplied by the drkkșepa[jya $]$ - by the Rcosine of the drkkșepa (drkkșepakotii), is multiplied by the semi-diameter (viskambhārdha) and divided by the bhujabhavadyujyā. The arc of this [result] is applied positively or negatively to the kâlalagna which is corrected by the difference in [own] longitude and right ascension (kalāprānāntara), depending on the difference or sameness in direction of the drkkșepa and the declination [from the kālalagna] (i.e. kālabāhu-apama), for obtaining the orient ecliptic point (prāglagna).

This verse gives the following relation for determining the orient ecliptic point or the udayalagna, in terms of the drkkșepajyā and the 'declination' $(\mu)$ derived from the kālalagna:

udayalagna $=$ kālalagna \pm nija-prāṇakalāntara

$$
\begin{aligned}
& \pm \text { cāpa }\left(\frac{k a \bar{a} l a b a \bar{a} h u \text {-apamajyā } \times d r k k s ̦ e p a j y \bar{a}}{d r k k s ̣ e p a k o t ̣ i} \times\right. \\
& \left.\frac{\text { vișkambhārdha }}{\text { bhujabhava-dyujyā }}\right)
\end{aligned}
$$

or,

$$
\begin{aligned}
\lambda_{l}=\alpha_{e} \pm\left|\lambda_{r}-\alpha_{e}\right| \pm & \\
R \sin ^{-1} & \left(\frac{R \sin \mu \times R \sin z_{d}}{R \cos z_{d}} \times \frac{R}{R \cos \mu}\right) .
\end{aligned}
$$

As the procedure described in the verse involves converting the kālalagna into the longitude of the rāśikuttalagna, the term kalāprānāntara in the verse is to be understood as the nija-prānakalāntara discussed in verse 31 .
The term $k \bar{a} l a b \bar{a} h u$-apamajy $\bar{a}^{12}$ is to be interpreted as the sine of the 'declination' $(\mu)$ derived using the kālalagna and is equivalent to (5). The term bhujabhava-dyujyā in the verse is to be understood as the day-radius corresponding to the declination $(\mu)$ derived from the bhuja of the $k \bar{a}$ lalagna, and is therefore equal to $R \cos \mu{ }^{13}$ Finally, the drkksepakoti is nothing but the cosine of the zenith distance of the drkkșepalagna, or $R \cos z_{d}$.

With the terms understood in this manner, the above relation can be easily derived as follows. Figures $5 \mathrm{a}$ and $5 \mathrm{~b}$ depict two instances when $\mu$ and $z_{d}$ are on the opposite sides, and the same side of the ecliptic respectively. From Figure $5 \mathrm{a}$ it is evident that the longitude $\left(\lambda_{l}\right)$ of the udayalagna $(L)$ is given by

$$
\lambda_{l}=\lambda_{r}+R L
$$

where $\lambda_{r}$ is the longitude of the rāśikūtalagna $(R)$. However, from verse 31 , we already know that

$$
\lambda_{r}=\alpha_{e} \pm\left|\lambda_{r}-\alpha_{e}\right|
$$

The length of the arc $R L$ can be determined as follows. In the spherical triangle $R E L$, by definition $E R=\mu$. Also, $R \hat{L} E=90-z_{d}$, is the angle between the ecliptic and the horizon. ${ }^{14}$ As the eastern cardinal point is the pole for the prime meridian, the angle $R \hat{E} L$ is equivalent to the length of the $\operatorname{arc} N J=N P+P J$. By definition, $N P=\phi$, while we have already shown $P J=\delta_{m} \cdot{ }^{15}$ Therefore,

$$
R \hat{E} L=\phi+\delta_{m}=z_{m},
$$

which is the zenith distance of the madhyalagna. Applying the sine rule in the spherical triangle $R E L$, we have

$$
\sin R L=\frac{\sin \mu \sin z_{m}}{\cos z_{d}} .
$$

However, from the triangle $Z M^{\prime} D^{\prime}$ in Figure $2 \mathrm{~b}$, we have

$$
\sin z_{m}=\frac{\sin z_{d}}{\cos \mu} .
$$

\footnotetext{
${ }^{12}$ It can be derived as कालबाहुना गणिता अपमज्या।

${ }^{13}$ Recalling that the radius of the diurnal circle of the Sun is equal to $R \cos \delta$, when its declination is $\delta$, it is worth noting the similarity of conceptions as well as terminologies coined to describe these parameters.

${ }^{14}$ See (17) in our previous paper.

${ }^{15}$ See our discussion of verse 36 .
} 


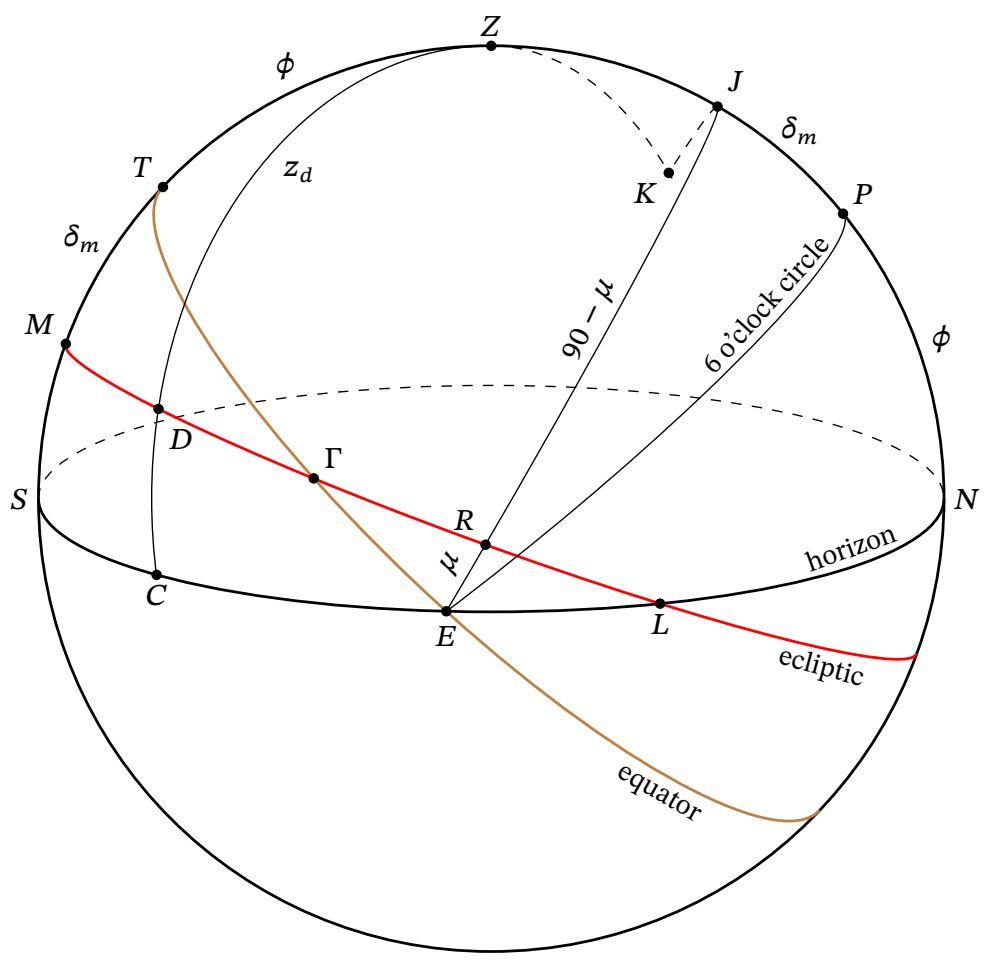

(a) Dṛkkșepajyā and kālabāhu-apamajyā on opposite sides of the ecliptic.

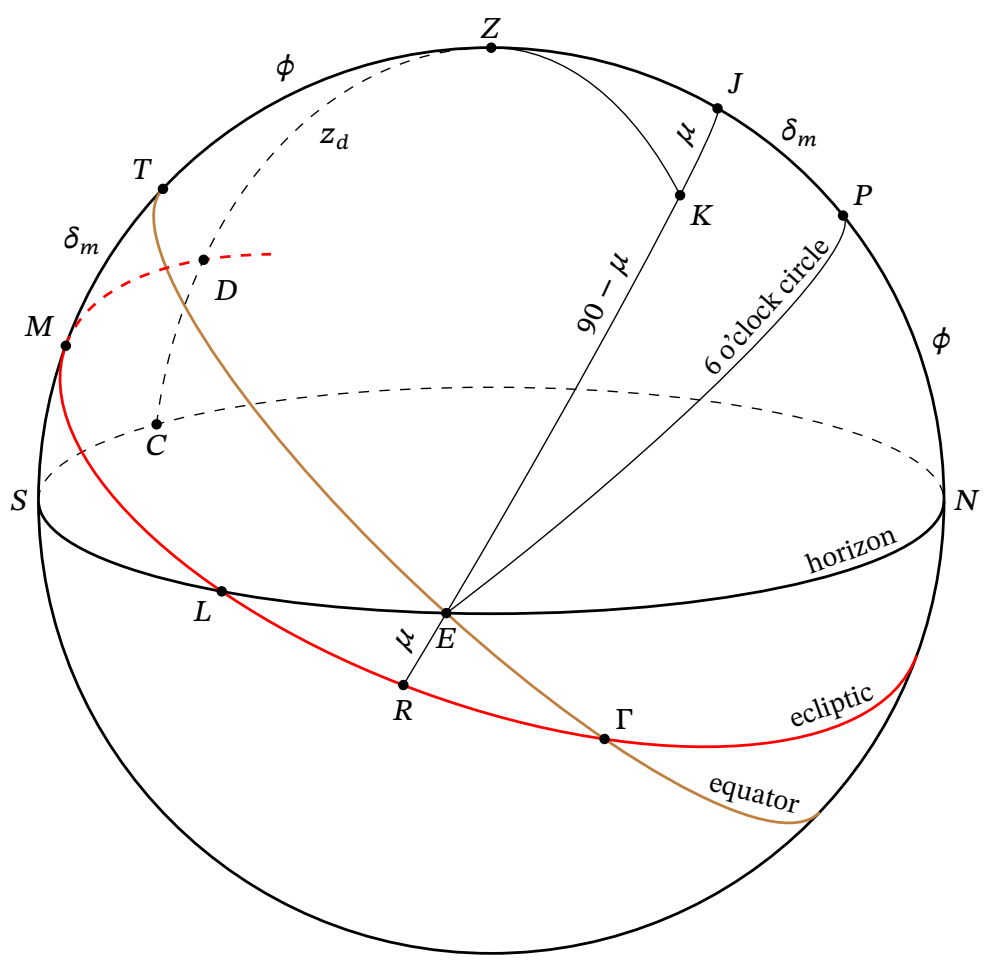

(b) Dṛkșepajyā and kālabāhu-apamajyā on the same side of the ecliptic.

Figure 5 Directions of dṛkkṣepajyā and kālabāhu-apamajyā in determining the udayalagna. 
Upon solving for the arc $R L$ using the above relation, we obtain the longitude of the udayalagna as

$$
\begin{aligned}
\lambda_{l}=\alpha_{e} \pm\left|\lambda_{r}-\alpha_{e}\right| & + \\
R \sin ^{-1} & \left(\frac{R \sin \mu \times R \sin z_{d}}{R \cos z_{d}} \times \frac{R}{R \cos \mu}\right) .
\end{aligned}
$$

When $\mu$ and $z_{d}$ are on the same side of the ecliptic as shown in Figure 5b, then it is evident that the arc $R L$ has to be subtracted from the longitude $\left(\lambda_{r}\right)$ of $R$ to obtain the longitude of $L$. Thus the verse states that the $\operatorname{arc} R L$ is to be added to $\lambda_{r}$ when $\mu$ and $z_{d}$ are on opposite sides of the ecliptic, and subtracted when they are on the same side of it. Thus, in general, we have

$$
\begin{aligned}
& \lambda_{l}=\alpha_{e} \pm\left|\lambda_{r}-\alpha_{e}\right| \pm \\
& R \sin ^{-1}\left(\frac{R \sin \mu \times R \sin z_{d}}{R \cos z_{d}} \times \frac{R}{R \cos \mu}\right),
\end{aligned}
$$

which is the same as (6).

The above expression can also be derived alternatively as follows. Upon combining the relations (13), (14), and (2) from our previous paper, we obtain

$$
\lambda_{l}=\lambda_{r} \pm R \sin ^{-1}\left(\frac{b \bar{a} h u \times R}{R \cos z_{d}}\right) .
$$

Further substituting for $b \bar{a} h u$ using (10) of our previous paper and for $\sin z_{m}$ therein using (8) of this paper, it can be easily seen that we again obtain (6). Comparing the above expression to (13) of the previous paper reveals that the $\operatorname{arcs} R L$ and $M D$ in Figures $5 \mathrm{a}$ and $5 \mathrm{~b}$ are of equal measure. That is, the separation of the udayalagna from the rāsikuttalagna is the same as the separation of the drkksepalagna from the madhyalagna. This is also directly evident from the fact that both the $\operatorname{arcs} M R$ and $D L$ in this figure are of comparable measure, equal to ninety degrees. $^{16}$

\subsubsection{Method 2}

दृक्ष्केपाहतकालबाहुजगुणात् दृक्षेपकोट्या हततात् अन्त्यक्रान्तिसमाहतात् ${ }^{17}$ भुजभवद्युज्याहतं चापितम्। स्वर्णं कालविलग्रके कृतकलाप्राणान्तरे च क्रमात् दिग्भेदैक्यवशात्तु गुण्यगुणयोः प्राग्लग्रसंसिद्धये ॥४३॥

\section{dṛksṣepāhatakālabāhujaguṇāt}

\footnotetext{
${ }^{16}$ From (2) and (14) of the previous paper respectively.

${ }^{17}$ Manuscripts read अन्त्यक्रान्तिसमाहृतात्. Emended as the relation requires multiplication by $R \sin \epsilon$ and not division.
}

\author{
drkkșepakotyā hṛtāt \\ antyakrāntisamāhatāt bhujabhava- \\ dyujyāhrtạ̣ cāpitam | \\ svarṇaṃ kālavilagnake krtakalā- \\ prāṇāntare ca kramāt \\ digbhedaikyavaśāttu guṇyaguṇayoḥ \\ prāglagnasamsiddhaye \|43\|
}

[The result] from the division of Rsine arising from the kälalagna-which is multiplied by the drkksepa[jya $]$ - by the Rcosine of the drkksepa (drkksepakotii), is multiplied by [the Rsine of] the last declination (antyakrānti) and divided by the bhujabhavadyujyā. The arc of this [result] is applied positively or negatively to the kālalagna which is corrected by the difference in [own] longitude and right ascension (kalāprāṇāntara), depending on the difference or sameness of directions of the multiplicand (gunya) and the multiplier (guna), for obtaining the orient ecliptic point (prāglagna).

In continuation of the rule discussed in the previous verse, this verse gives the following slightly modified alternate expression for obtaining the orient ecliptic point or the udayalagna:

$$
\begin{aligned}
& \text { udayalagna }=\text { kālalagna } \pm \text { nija-prānakalāntara }
\end{aligned}
$$

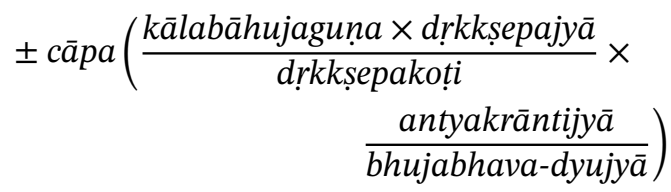

or,

$$
\begin{aligned}
& \lambda_{l}=\alpha_{e} \pm\left|\lambda_{r}-\alpha_{e}\right| \pm \\
& R \sin ^{-1}\left(\frac{R \sin \alpha_{e} \times R \sin z_{d}}{R \cos z_{d}} \times \frac{R \sin \epsilon}{R \cos \mu}\right)
\end{aligned}
$$

As in the previous verse, the term kalāprānāntara here too is to be understood as the nija-prānakalāntara of the kālalagna. Kālabāhujaguna is to be understood as the Rsine of the kālalagna or $R \sin \alpha_{e}$. The terms bhujabhavadyujya and drkkșepakoți, explained in the previous verse, and are equal to $R \cos \mu$ and $R \cos z_{d}$ respectively. The term antyakrāntijya $\bar{a}$ refers to the expression $R \sin \epsilon$. Having understood the terms, it can be seen that (9) can be obtained by simply substituting (5) for $\sin \mu$ in (6).

The sine inverse term in the above expression, as in the case of the expression found in the previous verse, gives 
the length of the arc $R L$, which is to be added to or subtracted from the longitude $\left(\lambda_{r}\right)$ of the rāśikūtalagna, to obtain the longitude $\left(\lambda_{l}\right)$ of the orient ecliptic point. The last quarter of this verse states the conditions for the positive and negative application of the $\operatorname{arc} R L$ to $\lambda_{r}$, which though appearing to be different, are equivalent to the conditions stated in the previous verse. This verse states that the arc $R L$ has to be added or subtracted to $\lambda_{r}$ depending upon the difference or sameness in the directions of the gunya (multiplicand) and the guna (multiplier). From the first line of the verse, it is evident that the guna refers to the drkksepajya $\left(R \sin z_{d}\right)$, which is the multiplier of the quantities $R \sin \alpha_{e}$ and $R \sin \epsilon$. The product of these two quantities, which from (5) we know to be $R \sin \mu$, is to be considered the gunya here. Therefore, the addition or subtraction of the arc $R L$ to $\lambda_{r}$ depends upon the difference or sameness in the directions of $R \sin \mu$ and $R \sin z_{d}$. This is equivalent to the rule stated in the previous verse, where we have also discussed its validity.

\section{Determining the ascendant from the unmanḍalalagna}

In this section we discuss the second of the three methods discussed in this paper for the determination of the udayalagna, as outlined in verses 44-49 of the second chapter of the Lagnaprakarana. This method involves first determining a quantity known as the drkkșepakotika or the rāsíikuttaprabhā, the procedure for which is described in verses 44-47. Next, using this result, verse 48 gives the relation for the computation of the longitude of the unmandalalagna, or the point of intersection of the ecliptic and the six o' clock circle. Finally, verse 49 gives the method of calculating the udayalagna using the unmandalalagna.

\subsection{Determining the drkkșepakotikā or the rāśikūțaprabhā}

काललग्रस्य कोट्युत्थां क्रान्तिमक्षगुणाहताम् ।
लम्बान्त्यद्युज्ययोर्धाते स्वर्णं कर्किमृगादितः ॥४8॥
कृत्वा त्रिजीवया हत्त्वा तत्र लब्धा भुजा भवेत् ।
काललग्रस्य बाहूत्था क्रान्तिरेवात्र कोटिका ॥४४॥
अनयोरथ दोःकोट्योः वर्गसंयोगतः पदम् ।

${ }^{18}$ Manuscripts read हृताम्. Emended as the relation requires multiplication by $R \sin \phi$ and not division.

\author{
राशिकूटप्रभा ज्ञेया सैव दृक्क्षेपकोटिका ॥४६॥ \\ kālalagnasya kotyutthām \\ krāntimakṣaguṇāhatām | \\ lambāntyadyujyayorghāte \\ svarnam karkimrgāditah $\|44\|$ \\ $k r t v \bar{a}$ trijīvayā hrtvā \\ tatra labdhā bhujā bhavet I \\ kālalagnasya bāhūtthā \\ krāntirevātra kotikā $\|45\|$ \\ anayoratha dohkotyoh \\ vargasamyogatah padam \\ rāśikūțaprabhā jñeyā \\ saiva dṛkkṣepakoṭikā ||46\|
}

Having applied the declination computed from the Rcosine of the kālalagna-which is multiplied by the Rsine of the latitude (aksaguna) - to the product of the Rcosine of the latitude (lamba) and the last day-radius (antyadyujyā) positively or negatively depending on [whether the kâlalagna is in] Cancer (karki) etc. or Capricorn ( $m r g a)$ etc., [the result] is divided by the radius (trijī $\bar{a})$. The result there would be the bhujā. The declination found from the kālalagna itself is the kotika here. Now, the square-root [taken] from the sum of the squares of these doh (i.e. bhujā) and koți should be known as the shadow of the pole of the ecliptic (rāsikūtaprabhā). That itself is the Rcosine of the dṛkșepa (dṛkkṣepakoțikā).

The above verses give a relation to determine the dṛkșepakoțikā or the rāsikūtaprabhā $\left(R \cos z_{d}\right)$, which has also been referred to previously as paraśanku in verses $37-38$, and as drrkkșepakoți in verses $42-43$. The given relation is

$$
R \cos z_{d}=\sqrt{b h u j \bar{a}^{2}+k o t i^{2}}
$$

where,

$$
\begin{aligned}
& \text { bhujā }=(\text { lambajyā } \times \text { antyadyujya } \pm \text { aksaguna } \times \\
& \text { kālalagnasya kotyutthā krāntijyā }) \div \text { trijīivā } \\
& =\frac{R \cos \phi \cdot R \cos \epsilon \pm R \cos \alpha_{e} \sin \epsilon \cdot R \sin \phi}{R},
\end{aligned}
$$

and

$$
\begin{aligned}
k o t ̣ i & =k \bar{a} \text { lalagnasya bāhūtthā krāntijyā } \\
& =R \sin \alpha_{e} \sin \epsilon .
\end{aligned}
$$




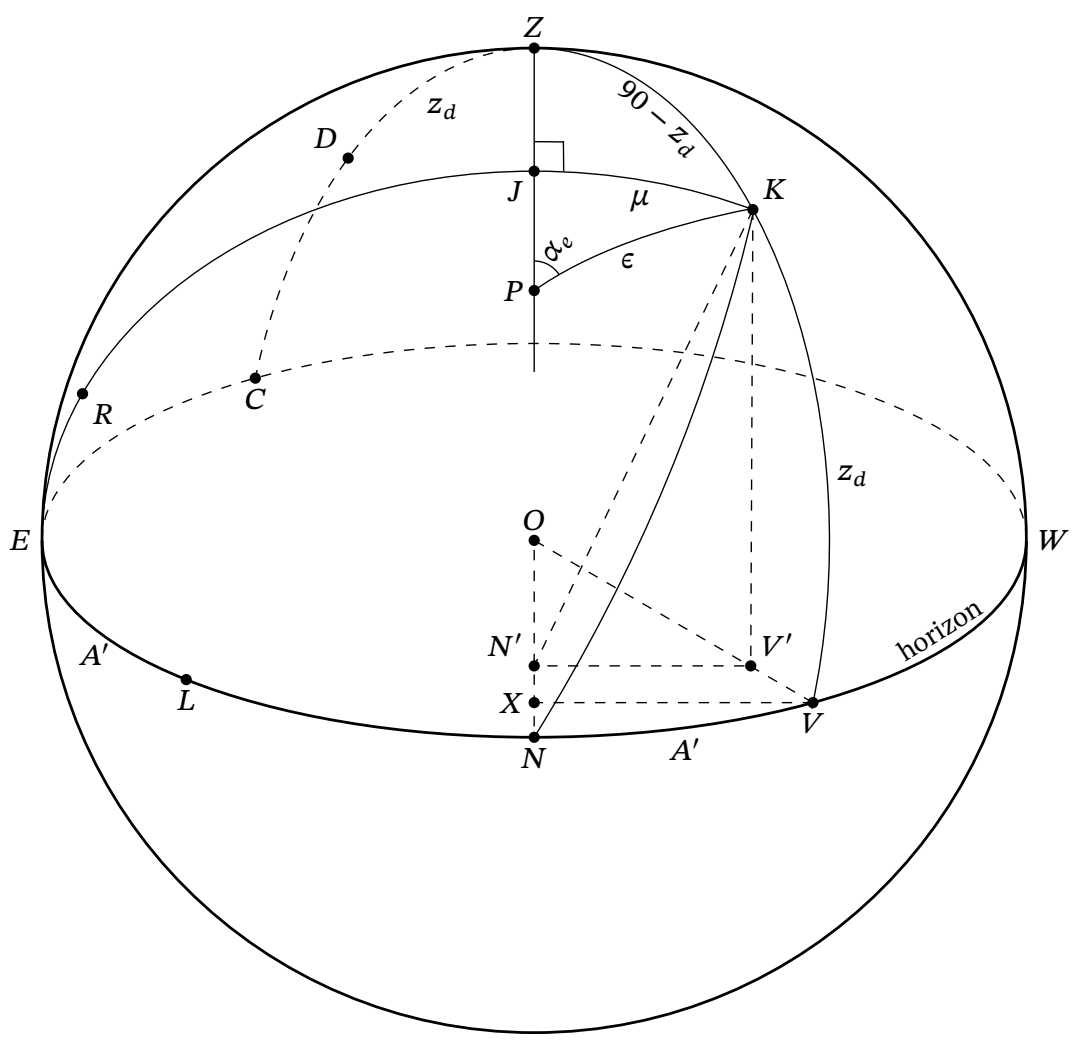

(a) Visualising the rāśikūtaprabhā.
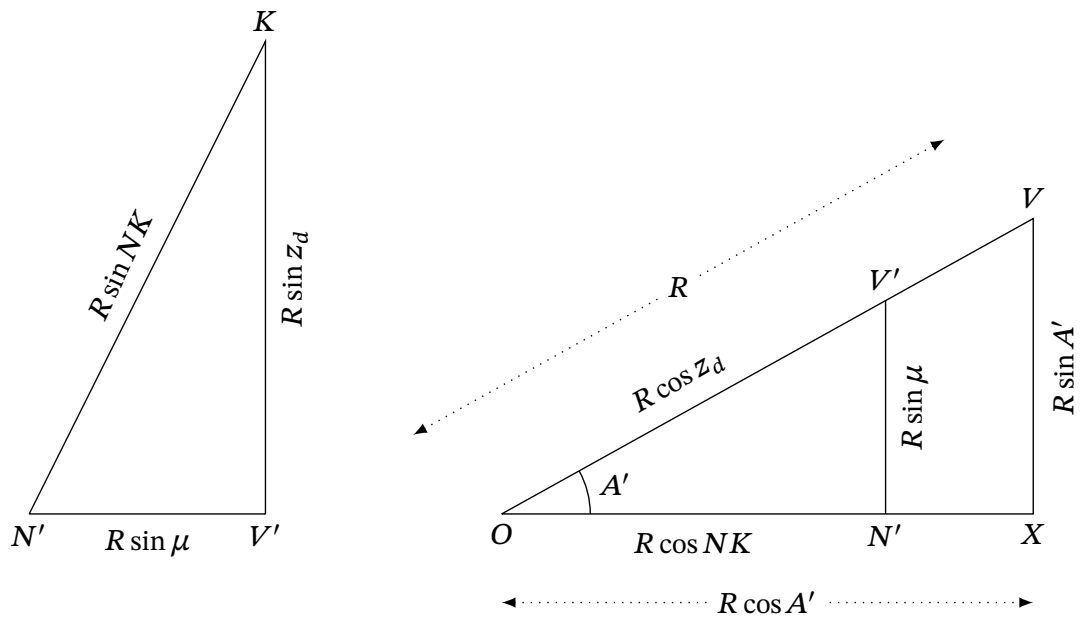

(b) The right-angled triangle having the sides rāśikūțaprabhā, bhujā and koṭi.

Figure 6 Determining the dṛkșepakotikā or the rāśikūtaprabhā. 


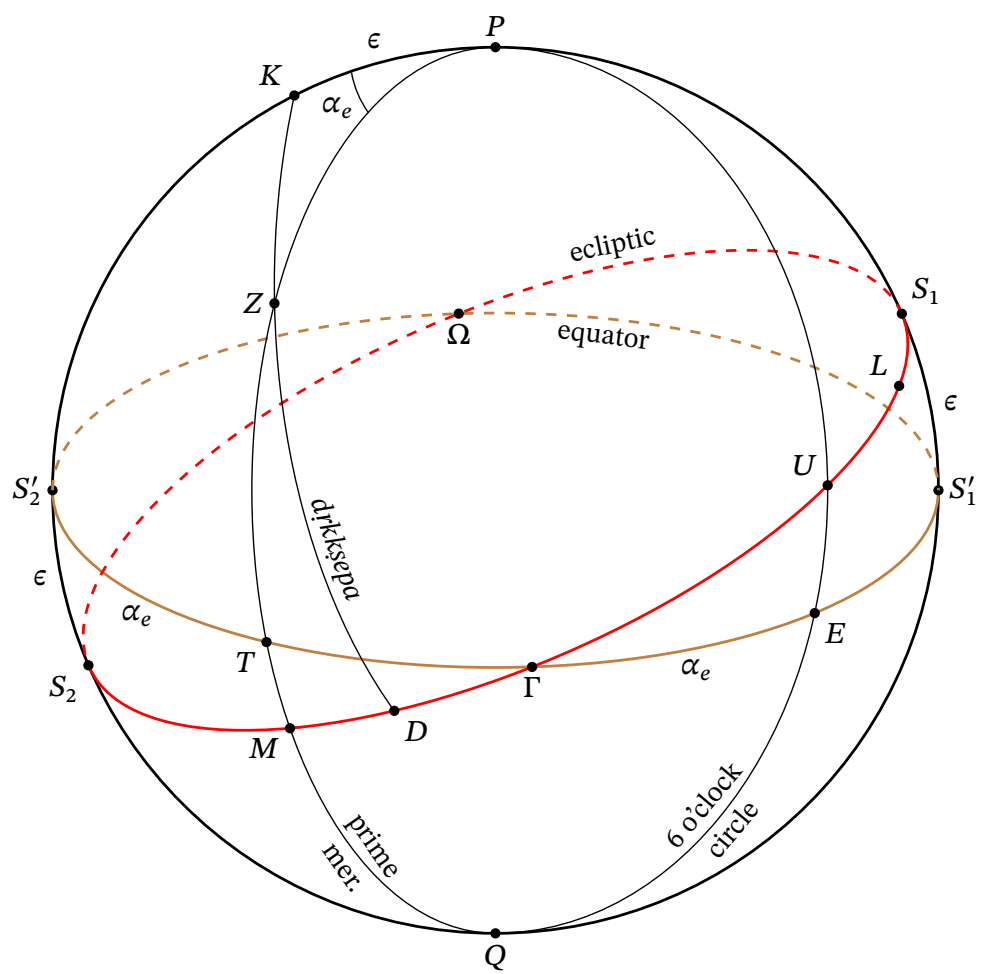

Figure 7 The hour angle of the pole of the ecliptic, and its angular separation from the celestial pole.

From (10), it is clear that the author has visualised a planar right-angled triangle inside the celestial sphere, whose hypotenuse is the desired quantity, i.e. drikksepa$k o t i k \bar{a}$, and whose sides are equivalent to the expressions for bhujā and kotit. We will show that this is the triangle $V^{\prime} N^{\prime} O$ in Figure 6a. This figure is the same as Figure 1, but depicts the northern hemisphere of the celestial sphere. Therefore, in this figure, the great circle arcs $N P J Z$ and $V K Z D C$ correspond to the prime meridian and the drkksepavrtta ${ }^{19}$ respectively. It may be noted that the portion of the prime meridian between the points $N$ and $P$ in this figure is not shown so that the desired planar triangles inside the celestial sphere can be seen clearly.

In this figure, the right-angled triangle $K V^{\prime} N^{\prime}$, whose side $K V^{\prime}$ is the gnomon corresponding to the pole of the ecliptic $(K)$, is perpendicular to the horizon. As the arc $K V=z_{d},{ }^{20}$ we have

$$
K V^{\prime}=R \sin z_{d}, \quad \text { and } \quad O V^{\prime}=R \cos z_{d} .
$$

\footnotetext{
${ }^{19}$ The great circle passing through the pole of the ecliptic and the drikkșepalagna.

${ }^{20}$ The zenith distance of the drkksepalagna is given by $Z D=z_{d}$. As $K D=Z V=90$, we have $K Z=90-z_{d}$, and $K V=z_{d}$.
}

Also, as $K N^{\prime}$ is the semi-chord corresponding to the arc $K N$, we have

$$
K N^{\prime}=R \sin N K, \quad \text { and } \quad O N^{\prime}=R \cos N K .
$$

In the right-angled triangle $K V^{\prime} N^{\prime}$, we now have

$$
N^{\prime} V^{\prime 2}=(R \sin N K)^{2}-\left(R \sin z_{d}\right)^{2},
$$

which can be rewritten as

$$
\begin{aligned}
N^{\prime} V^{\prime 2} & =\left(R \cos z_{d}\right)^{2}-(R \cos N K)^{2} \\
& =O V^{\prime 2}-O N^{\prime 2},
\end{aligned}
$$

which proves that the triangle $V^{\prime} O N^{\prime}$ is right-angled at $N^{\prime}$. This triangle has the drkkșepakotik $\bar{a}\left(R \cos z_{d}\right)$ as its hypotenuse. ${ }^{21}$ Now, we will show that the sides $O N^{\prime}$ and $N^{\prime} V^{\prime}$ correspond to the bhuja and koți given in the verse.

\section{Determining the koți}

To determine the koti $i$, consider the great circle arc KJRE in Figure 6a, which is the secondary to the ecliptic from

\footnotetext{
${ }^{21}$ In the figure, it is possible to conceive of the side $O V^{\prime}$ to be the 'shadow' of the gnomon $\left(K V^{\prime}\right)$ dropped from the pole of the ecliptic. This appears to be reason for calling it the rāsíikuttaprabhā.
} 
its pole $K$, and which also passes through the east cardinal point $(E)$. As $E$ is the pole for the prime meridian, the arc $K J R E$ is perpendicular to the prime meridian at $J$. Therefore, the semi-chord corresponding to the arc $K J$, whose measure is $\mu,{ }^{22}$ would be the perpendicular distance between $K$ and the plane of the prime meridian. That is,

$$
R \sin K J=R \sin \mu .
$$

As the point $V^{\prime}$ is the image of $K$ on the horizon, and the line $O N$ is the image of the plane of the prime meridian on the horizon, we also have

$$
\begin{aligned}
N^{\prime} V^{\prime} & =R \sin \mu \\
& =R \sin \alpha_{e} \sin \epsilon, \quad[u \operatorname{sing}(5)]
\end{aligned}
$$

which is the same as (12).

The expression for the koti can also be alternatively validated as follows. In Figure 6a, as the $\operatorname{arcs} N E=V L=90$, we have the $\operatorname{arc} N V=A^{\prime}$, which is the amplitude of the rising point of the ecliptic. Now, consider the similar triangles $V^{\prime} O N^{\prime}$ and $V O X$ in Figure 6b, where $V X=R \sin A^{\prime}$ corresponds to the Rsine of the arc $N V$. Applying the rule of proportionality of the sides of similar triangles, we have

$$
N^{\prime} V^{\prime}=\frac{R \sin A^{\prime} \times R \cos z_{d}}{R} .
$$

Now, in the spherical triangle $R E L$ in Figure 1, where $R$ is the rāsikuttalagna, and $L$ is the udayalagna, we have

$$
E \hat{R} L=90, \quad E R=\mu, \quad \text { and } \quad E L=A^{\prime} .
$$

Also, from (17) in our previous paper, the angle between the ecliptic and the horizon $R \hat{L} E=90-z_{d}$. Applying the sine rule in this spherical triangle, we have

$$
R \sin \mu=\frac{R \sin A^{\prime} \times R \cos z_{d}}{R} .
$$

Therefore, from (13) and (14), we have $N^{\prime} V^{\prime}=R \sin \mu$, which is the same as (5) and (12). By comparing (14) and (5), we can appreciate how apparently different pairs of physical quantities can give rise to the same result.

\footnotetext{
${ }^{22}$ The quantity $\mu$ has appeared in a number of relations, starting with verse 36, and corresponds to the 'declination' calculated from the kālalagna, given by the measure of the $\operatorname{arc} E R$ in Figure 1, as well as the expression (5). As $K$ is the pole for the ecliptic on which the rāsikuttalagna $(R)$ lies, and as $E$ is the pole for the prime meridian on which $J$ lies, we have $K R=J E=90$. Therefore, it can be seen that $K J=E R=\mu$.
}

To determine the bhuja, we require the hour angle of the pole of the ecliptic, as well as its angular separation from the celestial pole. The method to determine these quantities is discussed next.

\section{Determining the hour angle of the pole of the ecliptic, and also its angular separation from the celestial pole}

Figure 7 depicts the celestial sphere from the point of view of the equatorial plane. In this figure, the great circle arcs PZTMQ and PUEQ correspond to the prime meridian and the six o'clock circle respectively. Now, consider the great circle arc $P K S_{2}^{\prime} S_{2} Q$, which is a meridian passing through the pole of the ecliptic $(K)$, and meets the ecliptic at $S_{2}$. Naturally, this arc would also be a secondary to the ecliptic, which implies that it is perpendicular to the equator as well as the ecliptic. This is only possible when it intersects the ecliptic at the solstitial point $\left(S_{2}\right)$. As the solstitial point is the point of the maximum declination of the ecliptic, we have $S_{2} S_{2}^{\prime}=\epsilon$. Also, as $K S_{2}=P S_{2}^{\prime}=90$, we have $K P=S_{2} S_{2}^{\prime}$. Therefore, the angular separation between the celestial pole and the pole of the ecliptic is given by

$$
K P=\epsilon .
$$

Now, the hour angle $\left(H_{k}\right)$ of the pole of the ecliptic is given by the spherical angle $S_{2}^{\prime} P T$, or the measure of the $\operatorname{arc} S_{2}^{\prime} T$, where $T$ is the intersection of the prime meridian and the equator. As $S_{2}$ is the solstitial point, we have $S_{2}^{\prime} \Gamma=S_{2} \Gamma=90$. As the east cardinal point is the pole of the prime meridian, we also have $E T=90$. Therefore, we obtain $S_{2}^{\prime} T=\Gamma E$. However, as $\Gamma E$ is nothing but the $k \bar{a}$ lalagna $\left(\alpha_{e}\right),{ }^{23}$ we have the hour angle of the pole of the ecliptic

$$
H_{k}=S_{2}^{\prime} T=\alpha_{e} \text {. }
$$

\section{Determining the bhujā}

To determine the bhujā, consider the spherical triangle $N P K$ in Figure 8a. In this triangle, we have

$$
P N=\phi, \quad K P=\epsilon, \quad \text { and } K \hat{P} N=180-H_{k},
$$

where $H_{k}$ is the hour angle of the pole of the ecliptic. As $H_{k}=\alpha_{e}$ from (16), we have ${ }^{24}$

$$
K \hat{P} N=180-\alpha_{e} .
$$

\footnotetext{
${ }^{23}$ See our discussion of verse 30 in [7].

${ }^{24}$ In Figure 8a, the pole of the ecliptic is in the western hemisphere Instead, when the pole of the ecliptic is in the eastern hemisphere, we
} 


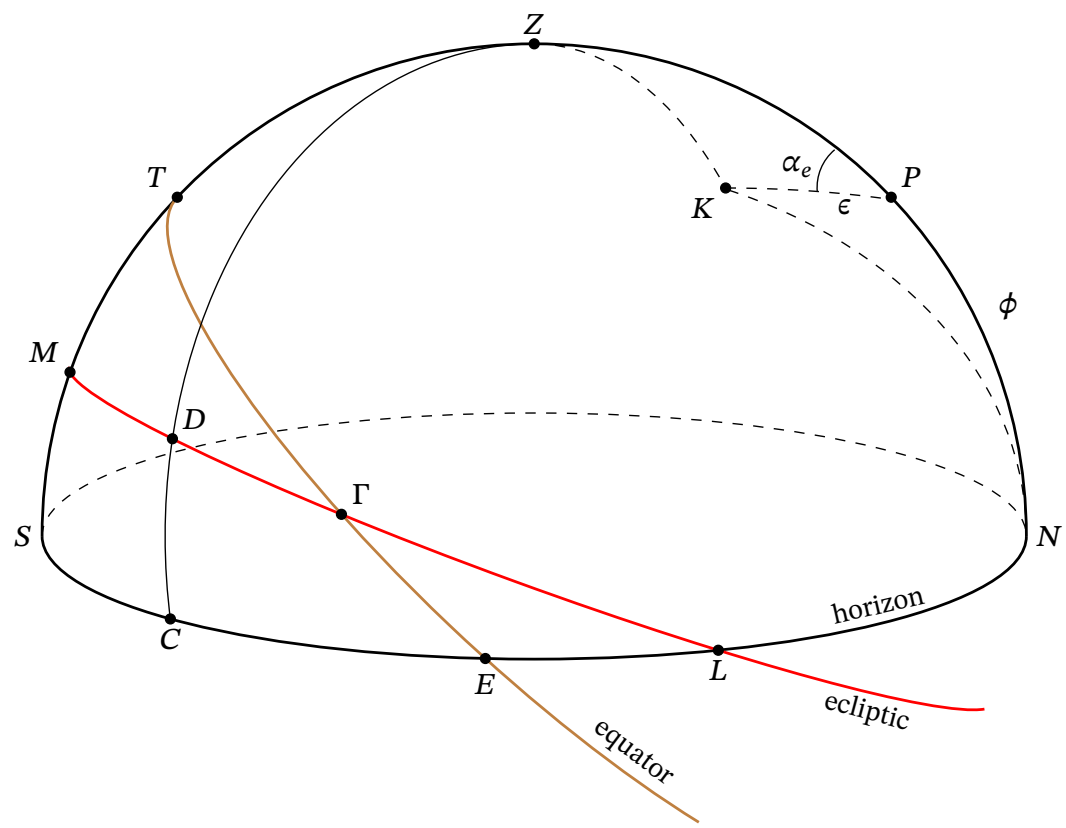

(a) Determining the bhujā in verses 44-46.

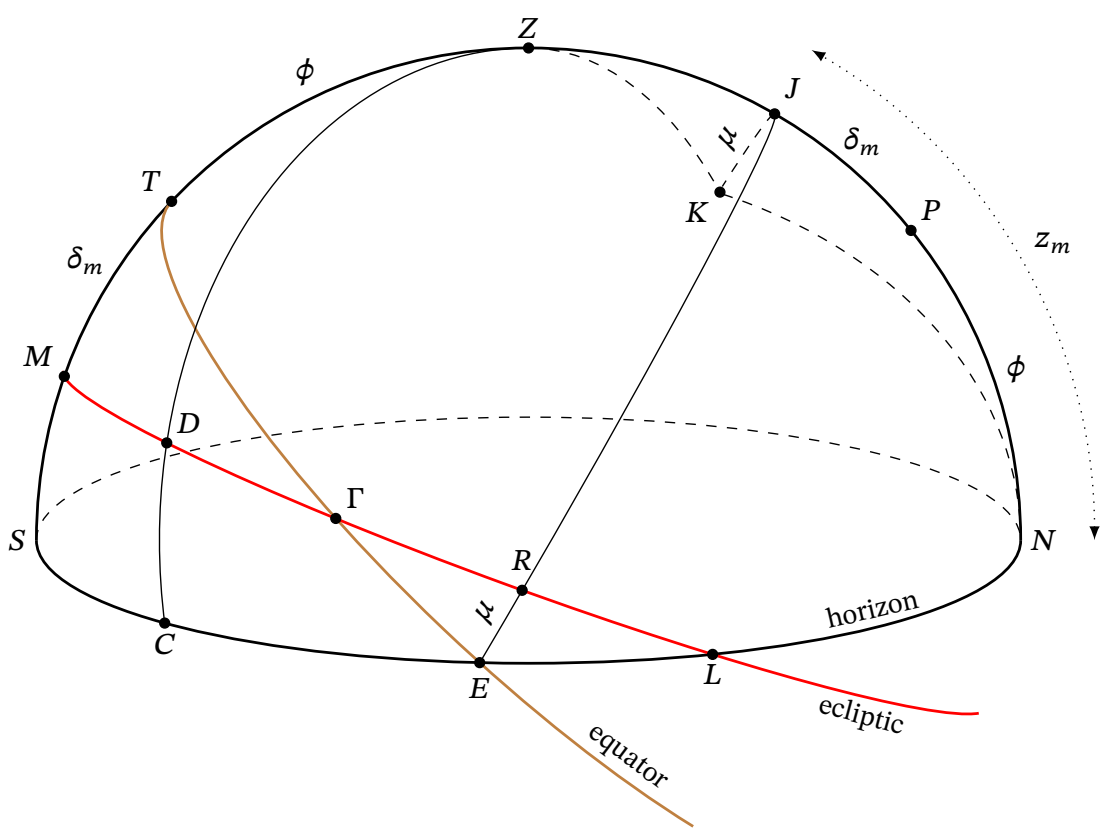

(b) Determining the equivalent dohprabhā in verse 47.

Figure 8 Determining the bhujā or the dohprabhā of the rāśikūṭa. 
Applying the cosine rule of spherical trigonometry in this triangle, we have

$$
\begin{aligned}
\cos N K & =\cos \phi \cos \epsilon+\sin \phi \sin \epsilon \cos \left(180-\alpha_{e}\right) \\
& =\cos \phi \cos \epsilon-\sin \phi \sin \epsilon \cos \alpha_{e} .
\end{aligned}
$$

The function $-\cos \alpha_{e}$ is positive in the range 90 to 270 degrees, and negative in the range 270 to 90 degrees. Thus, the above relation can be written as

$$
\cos N K=\cos \phi \cos \epsilon \pm\left|\sin \phi \sin \epsilon \cos \alpha_{e}\right|
$$

where the second term is to be applied positively when $\alpha_{e}$ is in the range of 90 to 270 degrees (i.e., Cancer etc.), and negatively when $\alpha_{e}$ is in the range of 270 to 90 degrees (i.e., Capricorn etc.). ${ }^{25}$ Multiplying both sides by $R$, the LHS of the above equation denotes the side $O N^{\prime}$ in the triangle $V^{\prime} N^{\prime} O$ in Figure 6a, and the RHS satisfies the magnitude and conditions for (11) stated in the verse.

In the first half of verse 46, the author refers to the bhuja as the doh. This same quantity is also referred to as the dohprabhā in the next verse, which gives an alternative method for calculating the same.

\section{काललग्रभुजाद्युज्या मध्यज्याकोटिकाहता। त्रिज्याप्ता वा भवेदत्र राशिकूटस्य दोःप्रभा ॥४७॥}

$$
\begin{aligned}
& \text { kālalagnabhujādyujyā } \\
& \text { madhyajyākotikāhatā । }
\end{aligned}
$$$$
\text { trijyāptā vā bhavedatra }
$$$$
\text { rāśikūṭasya doḥprabhā \|47\| }
$$

Or, the day-radius (dyujyā) corresponding to the $k \bar{a}$ lalagnabhujā is multiplied by the Rcosine of the madhyajyā (madhyajyākotikā) and divided by the radius (trijy $\bar{a})$. The remainder would be the dohprabhā of the pole of the ecliptic (rāsikiutta).

This verse gives the following relation to determine the dohprabhā, which is another term for the bhujā described

have $K \hat{P} N=H_{k}-180=\alpha_{e}-180$. As $\cos \left(180-\alpha_{e}\right)=\cos \left(\alpha_{e}-\right.$ $180)$, the result does not change in the following calculations.

${ }^{25}$ It may also be noted that $\sin \epsilon$ and $\sin \phi$ are always positive. in verses 44-46. The given expression is: ${ }^{26}$

$$
\begin{aligned}
& \text { dohprabhāa }=(k \bar{a} \text { lalagnabhujādyujyā } \times \\
& \text { madhyajyākoțikā) } \div \text { trijy } \bar{a} \\
& =\frac{R \cos \mu \times R \cos z_{m}}{R} \text {. }
\end{aligned}
$$

The term dohprabhā can be understood as the doh or the $b h u j \bar{a}$ (i.e. the lateral) in a right-angled triangle, where the hypotenuse is the rāsikūtaprabhā. Therefore, the dohprabhā is the same as the bhuja given by (11), and corresponds to the side $O N^{\prime}$ in the right-angled triangle $V^{\prime} O N^{\prime}$ in Figure 6a. In our discussion of verses 44-46, we have shown that $O N^{\prime}=R \cos N K$, where $N K$ is the great circle arc passing through the north cardinal point and the pole of the ecliptic. There, this quantity was determined using the spherical triangle NPK in Figure 8a. The expression given in (17) for this quantity can be derived by considering the spherical triangle $N J K$ in Figure $8 \mathrm{~b}$. In this triangle, we have $N J=z_{m},{ }^{27} J K=\mu$, and $N \hat{J} K=90 .{ }^{28}$ Applying the cosine rule in this spherical triangle, we have

$$
\begin{aligned}
\cos N K & =\cos \mu \cos z_{m} \\
\text { or, } \quad R \cos N K & =\frac{R \cos \mu \times R \cos z_{m}}{R} .
\end{aligned}
$$

which is the same as (17).

\subsection{Determining the unmandalalagna}

$$
\begin{aligned}
& \text { काललग्रे स्वकोट्युत्थं व्यस्तं प्राणकलान्तरम् । } \\
& \text { कुर्यात्तदा भवेदेतत् उन्मण्डलविलग्रकम् ॥४८॥ }
\end{aligned}
$$

kālalagne svakotyuttham

$$
\begin{aligned}
& \text { kuryāttadā bhavedetat } \\
& \text { unmaṇḍalavilagnakam \|48\| }
\end{aligned}
$$$$
\text { vyastam prāṇakalāntaram | }
$$

To the kālalagna, one should apply its own

\footnotetext{
${ }^{26}$ It may be noted that the expression kālalagnabhujādyujyā in the verse is to be interpreted as काललग्रभुजासंबन्धि-द्युज्या. When the Sun's declination is $\delta$, the corresponding day-radius or dyujya is equal to $R \cos \delta$. Similarly, when the 'declination' corresponding to the $k \bar{a} l a-$ lagna is $\mu$, its corresponding day-radius is to be taken as $R \cos \mu$.

${ }^{27}$ We have $J M=90$, as the madhyalagna is the pole of the great circle $\operatorname{arc} K J R E$ (see our discussion of verse 31). We also have $P T=90$, as $P$ is the pole for any point on the equator. Therefore, we have $P J=$ $T M=\delta_{m}$. Now, $N J=N P+P J=\phi+\delta_{m}=Z T+T M=z_{m}$.

${ }^{28}$ For the values of $J K$ and $N \hat{J} K$, see our discussion in the previous section titled 'Determining the kotii'.
} 
koți-prānakalāntara reversely. Then, this would be lagna on the six-o-clock circle (unmandalavilagna).

This verse gives the method to determine the longitude of the point of intersection of the ecliptic and the six o' clock circle. Called the unmandalalagna, this point is determined by applying the koți-prānakalāntara to the kālalagna reversely:

$$
\begin{aligned}
& \text { unmaṇdalalagna }= \text { kālalagna } \mp \\
& \text { koṭi-prānakalāntara } \\
& \text { or, } \quad \lambda_{u}=\alpha_{e} \mp\left|\lambda_{u}-\alpha_{e}\right|,
\end{aligned}
$$

where $\lambda_{u}$ is the longitude of the unmandalalagna, which is depicted by the point $U$ in Figures $9 \mathrm{a}$ and $9 \mathrm{~b}$.

The six o' clock circle is the meridian which passes through the east cardinal point $(E)$. As the unmandalalagna also lies on the this meridian, at the point of its intersection with the ecliptic, the right ascension corresponding to the longitude of the unmandalalagna is the arc $\Gamma E$, which is nothing but the kālalagna. Thus, applying the prānakalāntara to the longitude of the unmaṇdalalagna would give the kālalagna. That is,

$$
\alpha_{e}=\lambda_{u} \pm \text { prāṇakalāntara }=\lambda_{u} \pm\left|\lambda_{u}-\alpha_{e}\right|,
$$

where, the prānakalāntara can be obtained by any of the techniques described in an earlier paper. ${ }^{29}$ However, to determine the unmandalalagna from the kālalagna, the prānakalāntara has to be applied reversely. That is,

$$
\lambda_{u}=\alpha_{e} \mp\left|\lambda_{u}-\alpha_{e}\right|,
$$

which is the same as the relation given in the verse. It may be noted that, when considered with respected to the equatorial point $E$, the above prānakalāntara is called the koti-prānakalāntara, as $E$ and $U$ lie of the same meridian. ${ }^{30}$ Applying the nija-prānakalāntara to the kālalagna would give the rāśikūtalagna, ${ }^{31}$ and not the unmaṇdalalagna. Thus, to avoid confusion, the author clearly states in the verse that one has to apply the koț-prānakalāntara reversely to the kālalagna to obtain the unmandalalagna.

\footnotetext{
${ }^{29}$ See [8].

${ }^{30}$ See our discussion on verse 31 .

${ }^{31}$ Again, see our discussion on verse 31.
}

\subsection{Determining the udayalagna}

$$
\begin{aligned}
& \text { भूयस्तदुन्मण्डलकग्रके स्व- } \\
& \text { दोःक्रान्तिमौर्वाः पलताडितायाः। } \\
& \text { भकूटभाप्तस्य धनुश्च कुर्यात् } \\
& \text { व्यस्तं तदा वोदयलग्रकं स्यात् ॥४९॥ }
\end{aligned}
$$

bhūyastadunmaṇdalalagnake svadoḥkrāntimaurvyāḥ palatā ditāayāḥ।

bhakūtabhāptasya dhanuśca kuryāt vyastam tadā vodayalagnakaṃ syāt \|49||

Again, to that unmandalalagna, one should apply positively 32 or reversely (vyastam) the arc corresponding to the quotient obtained from the division of the product of the Rsine of the declination corresponding to own longitude [i.e., of the unmandalalagna] and the latitude [of the observer], by the bhakūtabhā. Then [the result] would be the udayalagna.

This verse gives the following relation to determine the udayalagna from the unmandalalagna:

$$
\begin{aligned}
& \text { udayalagna }=\text { unmaṇdalalagna } \pm \\
& \text { dhanus }\left(\frac{\text { svadoḥkrāntimaurvī } \times \text { palajyā }}{\text { bhakūtabhā }}\right) \\
& \text { or, } \quad \lambda_{l}=\lambda_{u} \pm R \sin ^{-1}\left(\frac{R \sin \delta_{u} \times R \sin \phi}{R \cos z_{d}}\right),
\end{aligned}
$$

where $\delta_{u}$ is the declination of the unmandalalagna, represented by the great circle arc $U E$ in Figures $9 \mathrm{a}$ and $9 \mathrm{~b}$. The term bhakūtabhā in the above expression is nothing but the rāśikūtaprabhā, or the dṛkșepakoțikā discussed in verse 46.

The validity of the above relation can be verified from the spherical triangle $U E L$ in Figures 9a and 9b, where we have $U E=\delta_{u}$, and $U \hat{E} L=\phi$. Also, from (17) in our previous paper, we have the angle between the ecliptic and the horizon $U \hat{L} E=90-z_{d}$. Applying the sine rule of spherical trigonometry, we have

$$
\sin U L=\frac{\sin \delta_{u} \times \sin \phi}{\cos z_{d}} .
$$

In Figure 9a, where the unmandalalagna is above the horizon, we can see that adding the arc $U L$ to the longitude of the unmandalalagna ( $\Gamma U$ ) gives the udayalagna $(\Gamma L)$. In Figure 9b, where the unmandalalagna is below

\footnotetext{
${ }^{32}$ The word kuryāt in the verse is interpreted here as 'apply positively'.
} 


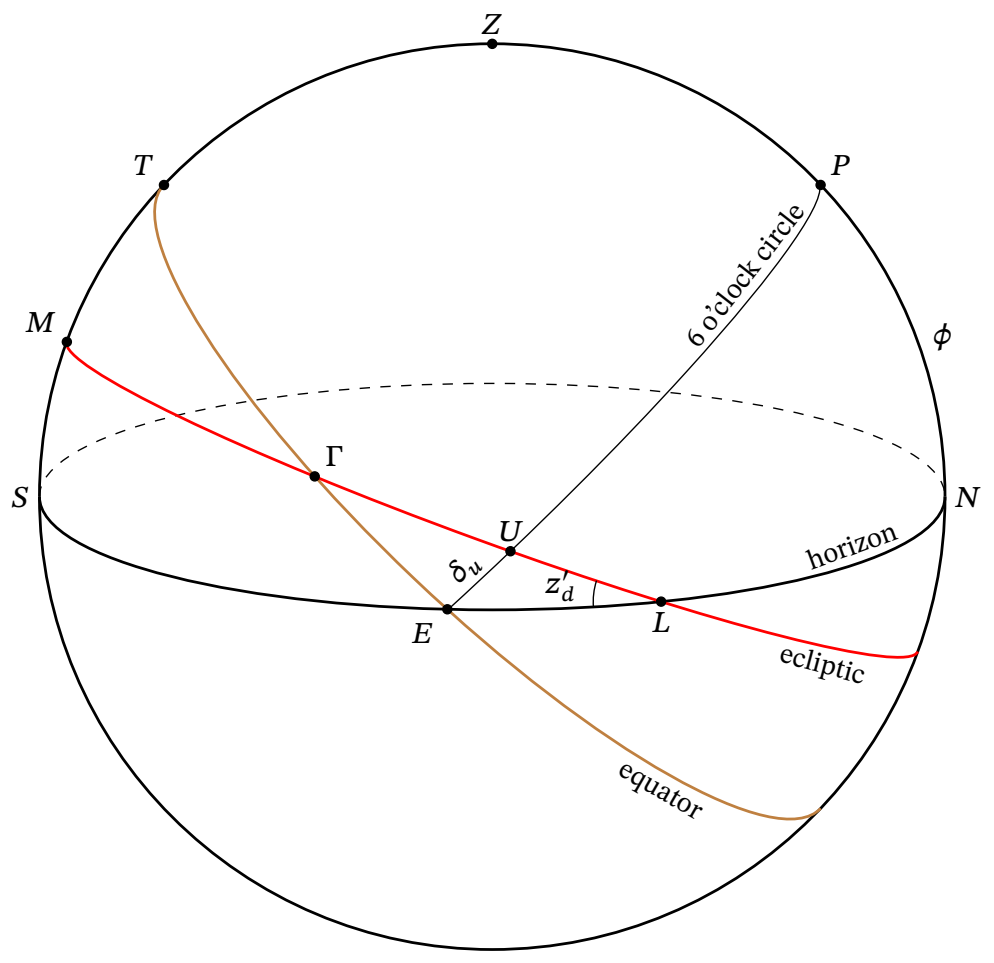

(a) Unmaṇdalalagna above the horizon.

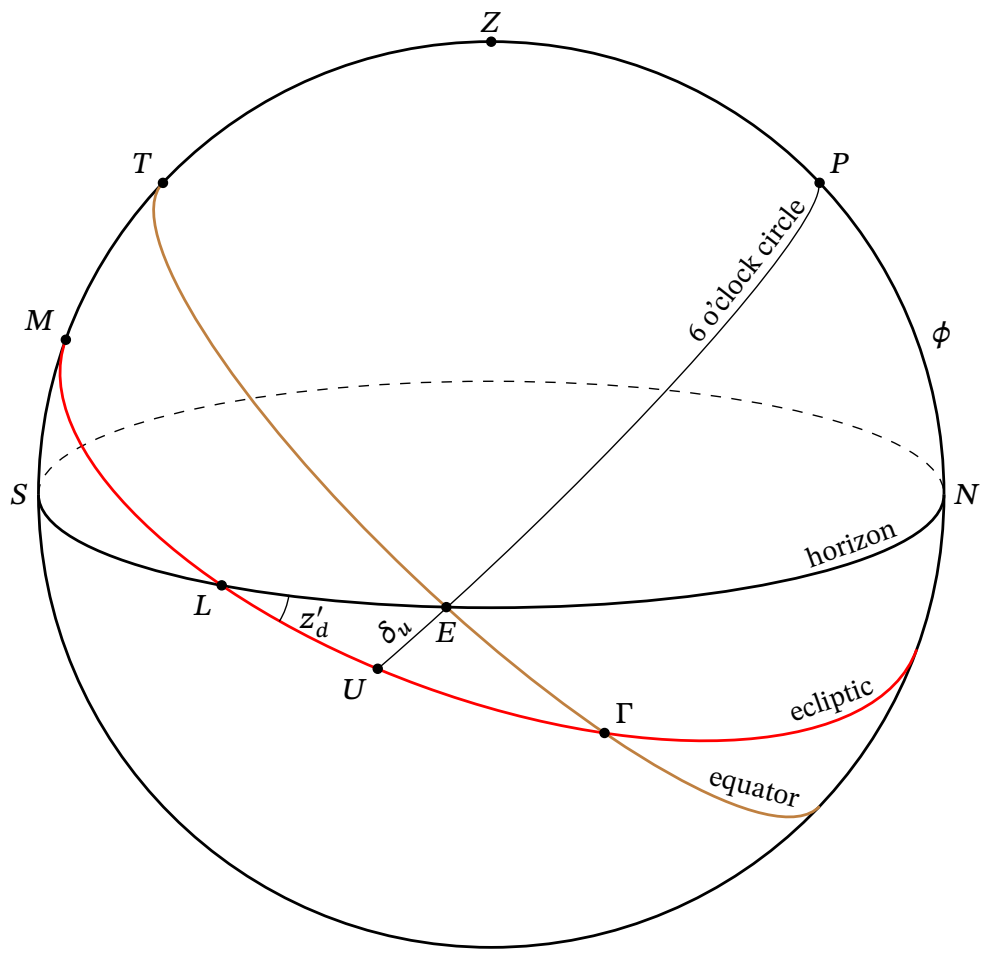

(b) Unmandalalagna below the horizon.

Figure 9 Determining the udayalagna from the unmandalalagna. 
the horizon, the arc $U L$ needs to be subtracted from the longitude of the unmandalalagna to obtain the udayalagna. Thus, the prescription given in the verse to add or subtract the arc $U L$ to the unmandalalagna to obtain the udayalagna is found to be valid.

\section{Determining the ascendant from the kālalagna}

In this section we discuss the third method for determining of the udayalagna as outlined in verses 50-52 of the second chapter of the Lagnaprakarana. Whereas verses 50 and 51 describe yet another technique for calculating the drkkșepajyā, verse 52 makes use of this quantity as well as the kälalagna to present a very interesting method for the determination of the udayalagna. Indeed, the method described in verse 52 attests to the spatial understanding and mathematical genius of Mādhava.

\subsection{Another method of obtaining the dṛkșepajyā}

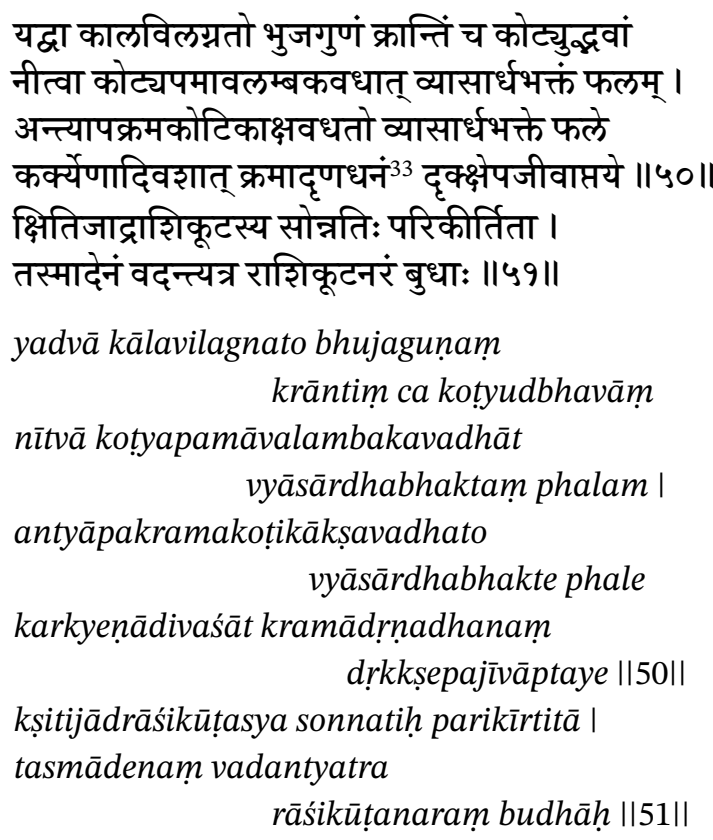

Or, having computed the Rsine from the kālavilagna, and [therefrom] the declination from its Rcosine (kotyapama), the product of the kotyapama and the Rcosine of the latitude (avalam-

${ }^{33}$ Manuscripts read क्रमाद्धनमृणं. Emended as the reverse order is required. baka) divided by the semi-diameter (vyāsārdha) is the result. This has to be applied negatively or positively to the result of the division of the product of the Rcosine of the last declination (antyapakramakoțika $)$ and [the Rsine of] the latitude (akșa) by the semi-diameter ( $v y \bar{a} s \bar{a} r d h a$ ), depending on [whether the kālalagna lies in the six signs] Cancer (karki) etc., or Capricorn (ena) etc., in order to obtain the Rsine of the drkkșepa (dṛkkșepajīvā).

That is stated to be the altitude of the pole of the ecliptic from the horizon. Therefore, scholars state it to be the gnomon of the pole of the ecliptic (rāśikūțanara).

These verses describe yet another method to determine the $d r k k s e p a j y \bar{a}$, and note that this quantity is equivalent to the gnomon (nara) corresponding to the pole of the ecliptic ( $r a \bar{s} s i k u ̄ t a)$. The relation prescribed in the verses is as follows:

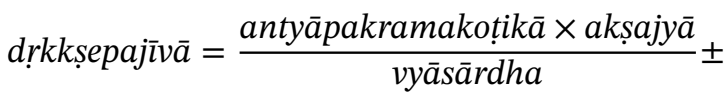

$$
\begin{aligned}
& \frac{\text { avalambakajyā } \times \text { kotyapama }}{\text { vyāsārdha }} \\
& \text { vyāsārdha }
\end{aligned}
$$

or,

$$
R \sin z_{d}=\frac{R \cos \epsilon \times R \sin \phi}{R} \pm \frac{R \cos \phi \times R \cos \alpha_{e} \sin \epsilon}{R}
$$

where the term kotyapama (i.e. koti-apama) is to be understood as the 'declination' calculated using the Rcosine of the kālalagna. Thus, this expression is equal to $R \cos \alpha_{e} \sin \epsilon$.

In our discussion of verses 44-46, we have already shown that the measure of the gnomon dropped from the pole of the ecliptic is equal to the $d r k k s e p a j y \bar{a}\left(R \sin z_{d}\right)$. This is evident in Figure 6a, where the gnomon $K V^{\prime}$ is equal to $R \sin z_{d}$. This same gnomon is also shown in Figure 10, where, by considering the spherical triangle $P K Z$, we can show the validity of (20). ${ }^{34}$ In this triangle, we have $P Z=90-\phi, K P=\epsilon$, and $K \hat{P} Z=\alpha_{e} \cdot{ }^{35}$ Noting that $K Z=90-z_{d}$, and applying the cosine rule in this triangle, we have

$$
\sin z_{d}=\cos \epsilon \sin \phi+\sin \epsilon \cos \phi \cos \alpha_{e} .
$$

\footnotetext{
${ }^{34}$ Nìlakantha in his Tantrasangraha describes a similar relation to determine the dṛkssepajyā. For a detailed discussion, see [15], pp. 242245 . The following proof borrows partly from this discussion. ${ }^{35}$ The latter two relations from (15) and (16) respectively.
} 


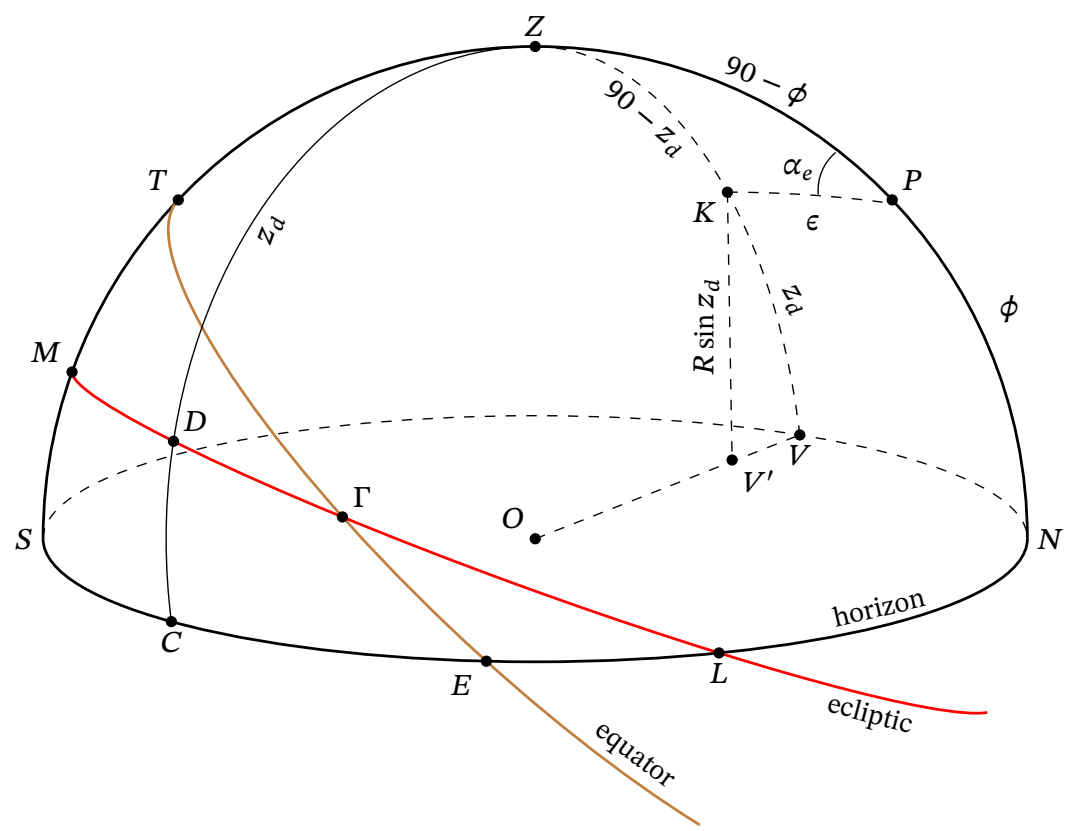

Figure 10 Another method of determining the drkksepa.

The function $\cos \alpha_{e}$ is positive in the range 270 to 90 degrees, and negative in the range 90 to 270 degrees. Thus, the above relation can be written as

$$
\sin z_{d}=\cos \epsilon \sin \phi \pm\left|\sin \epsilon \cos \phi \cos \alpha_{e}\right|,
$$

where the second term is to be applied positively when $\alpha_{e}$ is in the range of 270 to 90 degrees (i.e. Capricorn etc.), and negatively when $\alpha_{e}$ is in the range of 90 to 270 degrees (i.e. Cancer etc.) respectively. ${ }^{36}$ Multiplying by $R$, we have the expression

$$
R \sin z_{d}=R \cos \epsilon \sin \phi \pm R \sin \epsilon \cos \phi \cos \alpha_{e},
$$

which is equivalent to (20).

\subsection{Determining the udayalagna}

\section{कृत्वा दृक्ष्केपमक्षे धनमृणममुना}

हत्वा दृक्क्षेपकोट्या हृतमथ चरम-

$$
\text { काललग्रस्य दोर्ज्यां }
$$

$$
\begin{aligned}
& \text { क्रान्तिबाणेन हत्वा । } \\
& \text { हत्वान्त्यक्रान्तिमौर्व्या फलमिह तु पुनः } \\
& \text { चापितं काललग्रे }
\end{aligned}
$$

\section{स्वर्णं दिगभेदसाम्ये भुजगुणगुणयो:}

\section{प्राग्विलग्रस्य सिद्ध्रैै ॥५२॥}

\footnotetext{
${ }^{36}$ It may also be noted that $\sin \epsilon$ and $\cos \phi$ are always positive.
}

krtvā dṛkkșepamakșe dhanamrnnamamunā kālalagnasya dorjyām hatvā dṛkkṣepakotyā hrtamatha caramakrāntibāṇena hatvā |

hrtvāntyakrāntimaurvyā phalamiha tu punah cāpitam kālalagne svarnam digbhedasāmye bhujaguṇagunayoḥ prāgvilagnasya siddhyai \|52\|

Having applied the positive or negative [Rsine of the] drkksepa to the [Rsine of the] latitude ( $a k s ̦ a$ ), and having multiplied the Rsine of the kālalagna by this, [the result] is divided by the Rcosine of the drkkssepa (drkkșepakotii). Now, having multiplied [the previous result] by the Rversine of the maximum declination (caramakrāntibāna) and divided by the Rsine of the last declination (antyakrāntimaurvī), the result is converted to arc again. [That arc] becomes additive or subtractive to the kālalagna, depending on the difference and similarity of the directions of the bhujaguna (i.e. Rsine of the kālalagna) and the semi-chord (guna) [whose arc is determined above], in order to obtain the orient ecliptic point (prāglagna).

The above verse gives the following relation to deter- 
mine the udayalagna:

$$
\begin{aligned}
& \text { udayalagna }=k \bar{a} l a l a g n a \pm c \bar{p} a \\
& \left(\frac{(a k s ̦ a j y \bar{a} \pm d r k k s ̣ e p a) \times k \bar{a} l a l a g n a s y a \text { dorjyya }}{d r k k s ̦ e p a k o t ̦ i} \times\right. \\
& \left.\frac{\text { caramakrāntibāṇa }}{\text { antyakrāntimaurvī }}\right)
\end{aligned}
$$

or,

$$
\begin{aligned}
& \lambda_{l}=\alpha_{e} \pm R \sin ^{-1} \\
& \quad\left(\frac{\left(R \sin \phi \pm R \sin z_{d}\right) \times R \sin \alpha_{e}}{R \cos z_{d}} \times \frac{R \operatorname{versin} \epsilon}{R \sin \epsilon}\right) .
\end{aligned}
$$

The above expression reveals an impressive technique for determining the udayalagna, and really attests to the genius of the author of the text. This expression can be derived with the help of Figures 11 and 12. The former figure is representative of the situation when the kālalagna is in the first two quadrants ( $\left.0 \leq \alpha_{e} \leq 180\right)$, and the latter figure is representative of the situation when the $k \bar{a} l a-$ lagna is in the third and fourth quadrants $\left(180 \leq \alpha_{e} \leq\right.$ 360). Each of these cases is dealt separately below.

\section{Kālalagna in the first two quadrants}

Figure 11, which depicts the kālalagna in the first quadrant, is representative of the case when the kālalagna is in the first two quadrants. In this figure, we have drawn the great circle arc $E Y$ such that $\Gamma Y=\Gamma E$. As $\Gamma E=\alpha_{e}$, the longitude of the udayalagna is clearly

$$
\lambda_{l}=\Gamma Y+Y L=\alpha_{e}+Y L
$$

In what follows, we show how to determine $Y L$.

In the spherical triangle $\Gamma E Y$, as $\Gamma Y=\Gamma E$, we also have $\Gamma \hat{Y} E=\Gamma \hat{E} Y$. Let these two angles be denoted by $y$. Also, $Y \hat{\Gamma} E=\epsilon$. Using the sine rule, we have

$$
\sin Y E=\frac{\sin \alpha_{e} \sin \epsilon}{\sin y} .
$$

Applying the cosine rule for the side $Y E$, we have

$$
\cos Y E=\cos ^{2} \alpha_{e}+\sin ^{2} \alpha_{e} \cos \epsilon
$$

Now, applying the cosine rule for the side $\Gamma E$, we have

$$
\cos \alpha_{e}=\cos \alpha_{e} \cos Y E+\sin \alpha_{e} \sin Y E \cos y .
$$

Using (22) and (23) in the above equation, and simplifying, we obtain ${ }^{37}$

$$
\frac{\cos y}{\sin y}=\frac{\cos \alpha_{e} \times(1-\cos \epsilon)}{\sin \epsilon} .
$$

As $\Gamma \hat{E} L=90+\phi$, we have $Y \hat{E} L=90+\phi-y$. From (17) in our previous paper, we also have $Y \hat{L} E=90-z_{d}$. Now, applying the sine rule in the spherical triangle $Y E L$, we have

$$
\sin Y L=\frac{\sin Y E \times \cos (\phi-y)}{\cos z_{d}} .
$$

Substituting for $\sin Y E$ using (22), and simplifying by expanding $\cos (\phi-y)$, we get

$$
\sin Y L=\frac{\sin \alpha_{e} \sin \epsilon}{\cos z_{d}} \times\left(\sin \phi+\cos \phi \times \frac{\cos y}{\sin y}\right) .
$$

Using (24) and further simplifying, we obtain

$$
\begin{aligned}
\sin Y L= & \frac{\sin \alpha_{e} \times(1-\cos \epsilon)}{\cos z_{d} \times \sin \epsilon} \times \\
& \left(\sin \phi+\sin \phi \cos \epsilon+\cos \phi \cos \alpha_{e} \sin \epsilon\right) .
\end{aligned}
$$

Employing (20) in the second term of the RHS of the above equation, we get

$$
Y L=\sin ^{-1}\left(\frac{\sin \alpha_{e} \times(1-\cos \epsilon)}{\cos z_{d} \times \sin \epsilon} \times\left[\sin \phi+\sin z_{d}\right]\right) \text {. }
$$

Therefore, we have

$$
\begin{aligned}
\lambda_{l} & =\alpha_{e}+R \sin ^{-1} \\
& \left(\frac{\left(R \sin \phi+R \sin z_{d}\right) \times R \sin \alpha_{e}}{R \cos z_{d}} \times \frac{R-R \cos \epsilon}{R \sin \epsilon}\right) .
\end{aligned}
$$

It may be noted that the above result only holds when the kālalagna is in the first two quadrants. In this scenario, the amplitude of the udayalagna will always be northwards and the arc $Y L$ has to be added to the $k \bar{a} l a-$ lagna to obtain the udayalagna. The semi-chords corresponding to the kâlalagna $(\Gamma Y)$ and the arc $Y L$ lie in the plane of the ecliptic and will be perpendicular on either side to the radius of the ecliptic drawn from the point $Y$. Thus, the verse notes that the arc obtained above has to be added to the kälalagna when the semi-chords lie in opposite directions.

\footnotetext{
${ }^{37}$ This relation can also be directly obtained by applying the four part formula in the spherical triangle $\Gamma E Y$.
} 

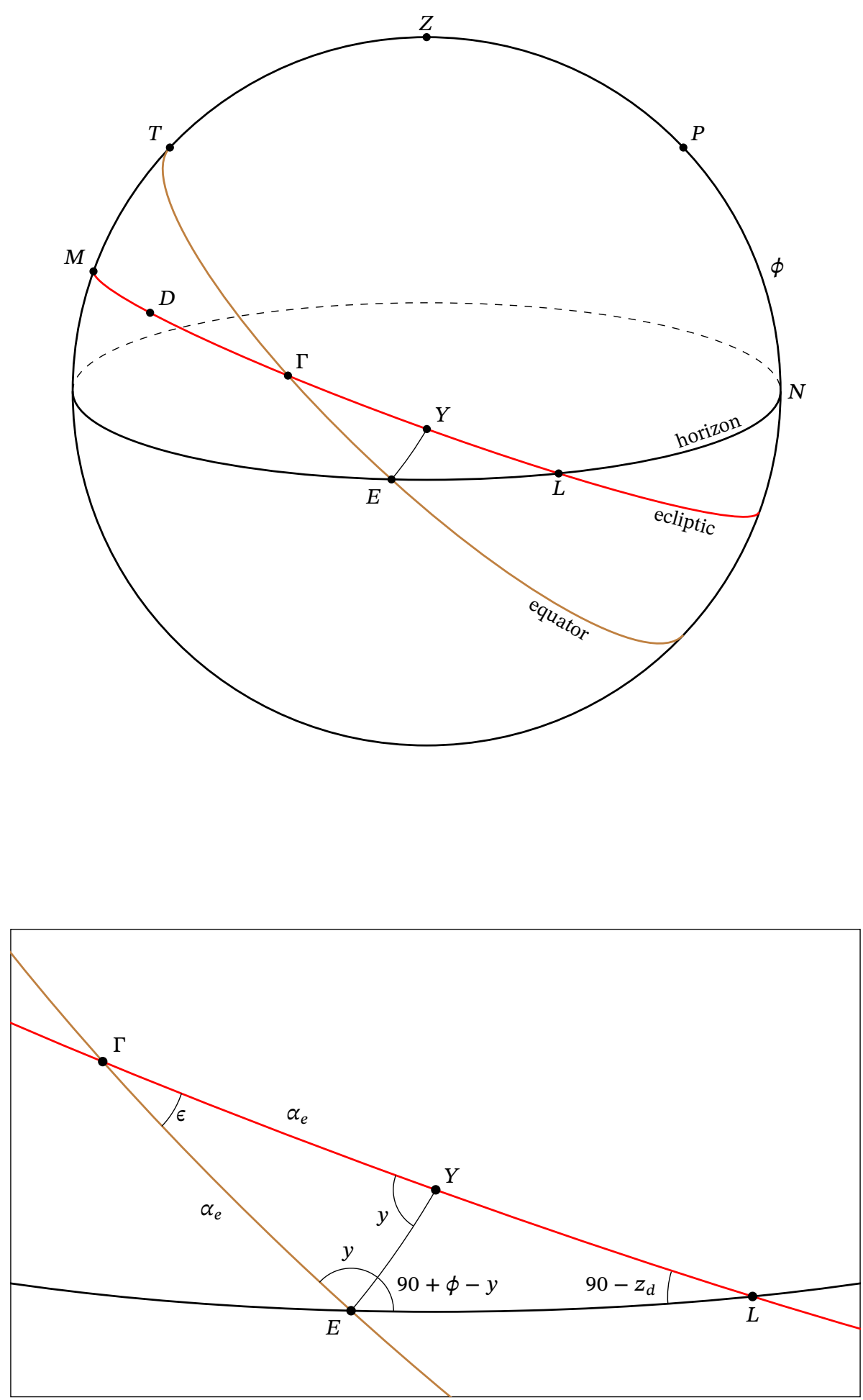

Figure 11 Determining the udayalagna when the kālalagna and the dṛkssepa are in the same direction. 

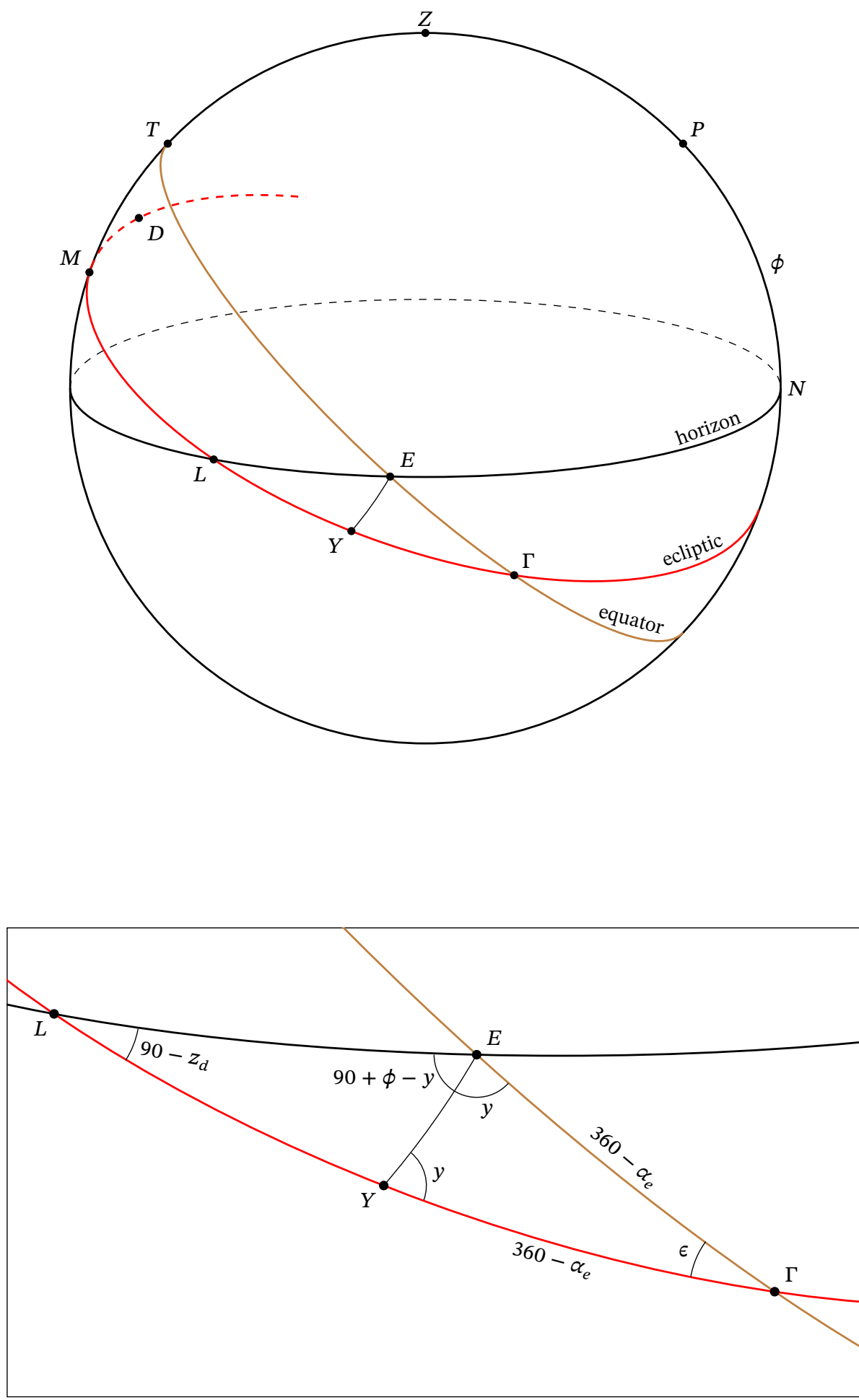

Figure 12 Determining the udayalagna when the kālalagna and the drkkșepa are in different directions. 


\section{Kālalagna in the third and the fourth quadrants}

When the kālalagna is in the third and fourth quadrants, the amplitude of the udayalagna is southwards. Figure 12 depicts one scenario when the kälalagna is in the fourth quadrant. In this figure, we have drawn the great circle $\operatorname{arc} E Y$ such that $Y \Gamma=E \Gamma=360-\alpha_{e}$. Thus, we have $\Gamma Y=\Gamma E=\alpha_{e}$, and the longitude of the udayalagna is clearly

$$
\lambda_{l}=\Gamma Y-Y L=\alpha_{e}-Y L .
$$

In this case, it can be shown through a similar procedure as followed earlier that the arc

$$
Y L=\sin ^{-1}\left(\frac{\sin \alpha_{e} \times(1-\cos \epsilon)}{\cos z_{d} \times \sin \epsilon} \times\left[\sin \phi+\sin z_{d}\right]\right) .
$$

and therefore,

$$
\begin{aligned}
\lambda_{l} & =\alpha_{e}-R \sin ^{-1} \\
& \left(\frac{\left(R \sin \phi+R \sin z_{d}\right) \times R \sin \alpha_{e}}{R \cos z_{d}} \times \frac{R-R \cos \epsilon}{R \sin \epsilon}\right) .
\end{aligned}
$$

In this scenario, the semi-chords corresponding to the kālalagna $(\Gamma Y)$ and the $\operatorname{arc} Y L$ lie in the plane of the ecliptic, and will be perpendicular on the same side to the radius of the ecliptic drawn from the point $Y$. Thus, the verse notes that the obtained arc has to be subtracted from the kālalagna in this situation.

Thus, it can be seen that the two relations (25) and (26) taken together yield (21). It may however be noted that while we have the expression $R \sin \phi \pm R \sin z_{d}$ in (21), the corresponding expressions in (25) and (26) contain only the positive sign. We are unable to ascertain the scenario in which the negative sign may be required.

\section{Conclusion}

The current paper discusses three broadly different approaches for the determination of the ascendant. These amply demonstrate Mādhava's remarkable mastery in visualising various intricate projections inside the celestial sphere and his ability to expertly intuit the relationships between them. The diversity of the approaches attest to the scientific curiosity of the author, and have great pedagogical significance for attaining mastery in any science. The remarkable results discussed in the paper highlight the pressing need to preserve and study these important category of texts, and to popularise their contributions among scholars and lay people alike. To this end, in further papers we will bring out many more interesting results presented in the Lagnaprakarana.

\section{Acknowledgements}

We would like to place on record our sincere gratitude to MHRD for the generous support extended to carry out research activities on Indian science and technology by way of initiating the Science and Heritage Initiative (SandHI) at IIT Bombay. We pay our obeisance to the late Prof. K. V. Sarma, who saved the Lagnaprakarana for future generations by painstakingly copying the crumbling manuscripts of the text. We are also extremely grateful to the Prof. K. V. Sarma Research Foundation, Chennai, for preserving and sharing the copies of these manuscripts, which has enabled us to study this interesting and important work. Finally, we would also like to profusely thank the anonymous referee for thoroughly reviewing our paper and making constructive suggestions.

\section{Bibliography}

[1] Āryabhața. Āryabhațīya. Ed., trans., and comm., with an introd., by Kripa Shankar Shukla and K. V. Sarma. New Delhi: Indian National Science Academy, 1976.

[2] Bhāskara. Siddhāntaśiromaṇi. With a comment. by Satyadeva Sharma. Varanasi: Chaukhamba Surabharati Prakashan, 2007.

[3] Brahmagupta. Brāhmasphuțasiddhānta. Ed. and comm. by Sudhakara Dvivedi. Reprint from The Pandit. Benares: Printed at the Medical Hall Press, 1902.

[4] Śrī Kṛ̣ṇa Candra Dvivedī, ed. Sūryasiddhānta. With the commentary Sudhāvarșin̄i of Sudhākara Dvivedī. Sudhākara Dvivedī Granthamālā. Varanasi: Sampurnanand Sanskrit University, 1987.

[5] Jñanarāja. Siddhāntasundara. Trans. and comm. by Toke Lindegaard Knudsen. Baltimore: John Hopkins University Press, 2014. 
[6] Jyeșțhadeva. Gaṇita-yukti-bhāṣā. Ed. and trans. by K. V. Sarma. With a comment. by K. Ramasubramanian, M. D. Srinivas, and M. S. Sriram. 2 vols. Culture and History of Mathematics 4. New Delhi: Hindustan Book Agency, 2008.

[7] Aditya Kolachana, K. Mahesh, and K. Ramasubramanian. "Determination of kälalagna in the Lagnaprakarana”. In: Indian Journal of History of Science 54.1 (2019), pp. 1-12.

[8] Aditya Kolachana, K. Mahesh, and K. Ramasubramanian. "Mādhava's multi-pronged approach for obtaining the prāṇakalāntara”. In: Indian Journal of History of Science 53.1 (2018), pp. 1-15.

[9] Aditya Kolachana, K. Mahesh, and K. Ramasubramanian. "Precise determination of the ascendant in the Lagnaprakarana-I”. In: Indian Journal of History of Science 54.3 (2019), pp. 304-316.

[10] Aditya Kolachana et al. "Determination of ascensional difference in the Lagnaprakarana". In: Indian Journal of History of Science 53.3 (2018), pp. 302-316.

[11] Lalla. Sișyadhīvrddhidatantra. With the commentary of Mallikārjuna Sūri. Ed., with an introd., by Bina Chatterjee. Vol. 1. 2 vols. New Delhi: Indian National Science Academy, 1981.

[12] Mādhava. “Lagnaprakaraṇa”. Manuscript 414B, ff. 53-84. Kerala University Oriental Research Institute and Manuscripts Library, Thiruvananthapuram.

[13] Mādhava. "Lagnaprakaraṇa”. KVS Manuscript No. 37a. Prof. K. V. Sarma Research Foundation, Chennai.

[14] Mādhava. “Lagnaprakaraṇa”. KVS Manuscript No. 37b. Prof. K. V. Sarma Research Foundation, Chennai.

[15] Nīlakaṇtha Somayājī. Tantrasañgraha. Trans. and comm. by K. Ramasubramanian and M. S. Sriram. Culture and History of Mathematics 6. New Delhi: Hindustan Book Agency, 2011.

[16] Putumana Somayājī. Karaṇapaddhati. Trans. and comm. by Venketeswara Pai et al. Culture and His- tory of Mathematics 9. New Delhi: Hindustan Book Agency, 2017. 